\title{
Debt Financing, Survival, and Growth of Start-Up Firms
}

\author{
Rebel Cole \\ DePaul University \\ Chicago, IL 60404 \\ phone: (312) 362-6887 \\ fax: (312) 362-6566 \\ rcole@depaul.edu \\ Tatyana Sokolyk \\ Brock University \\ St. Catharines, ON \\ phone: (905) 688-5550 ext. 4781 \\ fax: (905) 378-5723 \\ tsokolyk@brocku.ca
}

\begin{abstract}
:
We use data from the Kauffman Firm Surveys to analyze how the initial capital-structure decision of a U.S. start-up firm affects its subsequent survival and growth prospects. First, we analyze whether start-up capital structure explains whether or not a firm will remain in business after its first three years. We find that a firm using debt in its capital structure, and, in particular, business debt, is significantly more likely to survive. Second, we analyze whether start-up capital structure explains how fast a firm grows during its first three years. We find that a firm using debt, and, in particular, business debt, grows faster. In other words, the initial capital structure decision of a start-up firm does, indeed, matter - in terms of both its survival and growth. We also analyze what factors explain a start-up's decision to use credit, and, conditional upon using credit, its decision as to what type of credit to use-business or personal credit. We find that both firm and owner characteristics explain the use of credit.
\end{abstract}

Keywords: availability of credit, bank credit, capital structure, entrepreneurship, Kauffman, KFS, start-up, survival

JEL Classifications: G21, G32, J71, L11, M13

We are grateful to the Kauffman Foundation for providing access to the NORC Enclave. Any opinions, findings, and conclusions or recommendations expressed in this material are those of the authors and do not necessarily reflect the views of the Ewing Marion Kauffman Foundation. 


\section{Introduction}

How do start-up firms finance their assets, and why does it matter? According to most corporate finance textbooks, the capital-structure decision — how to finance a firm's assets - is one of the three most important decisions facing a financial manager; second in importance only to the capital-budgeting choice. ${ }^{1}$ Yet, we know very little about how the manager of a start-up firm decides on the capital stack of various types of debt and equity she will use to finance her firm's assets because most existing empirical studies of capital structure have focused on large publicly traded corporations, for which data are readily available. ${ }^{2}$

This study expands the capital-structure literature by analyzing the effect of the initial capital structure decision on subsequent firm survival and growth prospects. Using data from the Kauffman Firm Surveys (KFS) of U.S. start-up firms, we document important new evidence along several dimensions. We find that larger and better quality firms are more likely to use credit at the firm's start-up. Furthermore, among firms that use credit, there are significant differences between firms using business credit and firms using personal credit. Better quality firms are more likely to use business credit and less likely to use personal credit.

Importantly, the decision to use credit at the firm's start-up does indeed matter for subsequent firm outcomes. A start-up firm using debt grows its revenues faster and is significantly more likely to survive the critical first three years of operation than does a start-up firm using no debt. This result is robust to controls for the initial firm and owner characteristics

\footnotetext{
${ }^{1}$ See, e.g., Brealey, Myers, and Allen (2011) and Ross, Westerfield and Jaffe (2012), two of the leading corporate finance textbooks used in U.S. MBA programs.

${ }^{2}$ Four notable exceptions are Brav (2009), who analyzes data on privately held U.K. companies; Ang, Cole and Lawson (2010) and Cole (2008, 2013), who analyze data on privately held U.S. companies from the Federal Reserve's Surveys of Small Business Finances; and Robb and Robinson (2013), who, as we do, analyze data on U.S. start-up companies from the Kauffman Firm Surveys.
} 
and to controls for the endogeneity between the probability of receiving debt financing and performance outcomes. It also holds in the propensity-matching-score analysis, which shows that borrowing firms outperform otherwise similar non-borrowing firms in terms of revenues and survival. Notably, it is the use of business debt, as opposed to personal debt, which matters the most for firm's performance and survival.

Our new evidence on debt financing at the initial stage of business formation contributes to several strands of the existing literature. First, we contribute to the literature on debt financing of privately held firms (see, e.g. Ang, 1992; Berger and Udell, 1998; Cole, 2008; Brav, 2009; Ang, Cole and Lawson, 2010; Robb and Robinson, 2012; Cole, 2013) by documenting that the decision to use debt at the firm's start-up matters for the critical subsequent firm outcomes of survival and growth. Second, we contribute to the literature on availability of credit to small firms (see, e.g., Petersen and Rajan, 1994; Berger and Udell, 1995; Cole, 1998) by documenting what types of firms are more likely to receive debt financing at the initial stage of business formation. Third, we contribute to finance and entrepreneurship literatures that seek to determine what initial factors affect the survival and growth of new entrepreneurial firms (Cassar 2004; Schwienbacher 2013). Finally, we contribute to the growing literature that analyzes start-up firms using data from the Kauffman Firm Surveys. (See, e.g., Coleman and Robb 2009; Fairlie and Robb 2009; Cole 2011; Coleman and Robb, 2011; Robb and Watson, 2011; and Robb and Robinson, 2012).

Our study has several important implications for economic policymakers and investors interested in entrepreneurial start-up firms. Without a doubt, small firms are vital to the U.S. economy. According to the U.S. Small Business Administration, small firms are responsible for almost two out of three net new private sector jobs; and almost half of both private-sector 
employment and private sector output. ${ }^{3}$ A start-up's first three years in operation is a critical stage for its survival and performance. A better understanding of what types of firms use credit and the sources of credit finance can help policymakers to take actions to increase the availability of credit to start-up firms that will potentially lead to the creation of more jobs and faster economic growth. ${ }^{4}$ Furthermore, a better understanding of the importance of credit use at the firm's start-up should provide policymakers with guidance in how to tailor economic and tax policies to help start-up businesses to obtain credit when they need credit, thereby increasing both employment and productivity. This has especially important implications for tax reform proposals that would limit the deductibility of interest on business debt, which would increase the cost of credit to small firms. Additionally, the results of our study provide some guidance to the investors considering providing capital to new entrepreneurial firms. We show that entrepreneurial firms that are able to secure business credit from external sources at the firm's start-up tend to outperform other start-up firms.

The remainder of our study is structured as follows. In section 2, we review relevant studies of small firms and develop hypotheses. In section 3, we describe our data and methodology. In section 4, we present our results, following by a summary and conclusions in section 5 .

\footnotetext{
${ }^{3}$ See "frequently asked questions" at http://www.sba.gov/sites/default/files/FAQ_Sept_2012.pdf.

${ }^{4}$ Recent such policies include the Small Business Lending Fund, which provided capital to community banks and community development loan funds as an incentive to increasing their lending to small firms; and the 7(a) Loan Program of the U.S. Small Business Administration, which provides loans to qualifying small firms.
} 


\section{Literature Review and Hypotheses}

\subsection{Capital Structure of Closely Held Firms}

Harris and Raviv (1991) review the theories of capital structure. The pecking order theory of financing demonstrates that capital structure is driven by firms' desire to finance new investments, first internally, then with low-risk debt, and finally with equity (Myers, 1984). According to the trade-off theory, a company chooses how much debt and how much equity to use by balancing the costs (i.e., the dead-weight costs of bankruptcy) and benefits (i.e., tax saving) of debt (Kraus and Litzenberger, 1973). A large body of empirical research has developed around these theories. We limit our review of the literature to the studies examining closely held firms.

Cole $(2008,2013)$ uses data from the Federal Reserve's Survey of Small Business Finances (SSBFs) to examine whether these theories explain the capital structure of small, privately held firms in the U.S. His results are broadly supportive of the pecking-order theory, in that leverage is negatively related to firm size, age, profitability and credit quality; and positively related to tangibility and limited liability. In a related paper, Cole (2009) analyzes differences between small U.S. firms that do and do not use credit. He finds that about one in five small firms use no credit whatsoever; and that firms using no credit are significantly smaller, more profitable, more liquid and of better credit quality than borrowing firms. Cole concludes that this evidence is generally consistent with the pecking-order theory of firm capital structure.

Ang, Cole and Lawson (2010) also use data from the Fed's SSBFs to analyze capital structure at privately held U.S. firms, but limit their analysis to firms owned entirely by a single individual. They find that personal risk tolerances account for $30 \%-60 \%$ of the explained variation in capital structure at these firms, and that leverage is positively related to owner age, 
experience, and sophistication, as well as to firm size and the number of financial institutions with which the firm has relationships.

A large number of articles, dating back at least to Wendt (1946), have examined the issue of availability of credit to small businesses. We limit our review of the literature to the studies that have appeared in the financial economics literature during the past two decades and have used the SSBFs data.

Petersen and Rajan (1994) were the first to analyze credit availability to small businesses using data from the SSBFs. They find that close ties with creditors lead to greater availability of credit at lower rates of interest and highlight the importance of firm-lender relationships in the allocation of credit. Berger and Udell (1995) extend Petersen and Rajan by analyzing the lines of credit, a type of lending where relationships should be especially important. They document that loan rates are lower for firms with longer firm-lender relationships. Cole (1998), on the other hand, focuses on the lender's decision whether or not to extend credit and finds that the existence rather than the length of the firm-lender relationship affects the likelihood of a lender extending credit to the firm.

Several studies analyze whether owner's race and gender influence the availability of credit for small businesses. Cavalluzo and Cavalluzo (1998) find little variation in credit availability by owner's gender but significant differences by owner's race. Cavalluzzo, Cavalluzzo and Wolken (2002), Blanchflower et al. (2003), and Cavalluzo and Wolken (2005) also find significant differences in availability of credit by owner's race. Furthermore, Coleman (2002) finds that small businesses with black owners are more likely to be denied borrowers and are more likely to be discouraged borrowers. 
Fairlie and Robb (2007) analyze confidential data from the Characteristics of Business Owners Survey conducted by the U.S. Census for evidence regarding why Black-owned businesses are smaller, less profitable and less likely to survive than white-owned firms. They find that the lack of prior work experience negatively affects outcomes of Black-owned firms.

Blanchard, Zhao, and Yinger (2008) examine data from the 1998 SSBF for evidence of discrimination against minority-owned firms. They find that both Black-owned and Hispanicowned firms are significantly more likely to be denied credit, which they interpret as strong, but not conclusive, evidence of discrimination by lenders against minorities

Robb, Fairlie, and Robinson (2009) use data from the Kauffman Firm Survey to provide new evidence on access of minority-owned start-up firm to financial capital. They find that Black-owned firms face significantly greater difficulty in obtaining financial capital than do white-owned firms.

Cole (2010) also looks at data from the 1993, 1998 and 2003 SSBFs to provide evidence on what types of firm use trade credit, use bank credit, use both, or use no credit. He finds that about one in five firms use no credit whatsoever, financing assets with $100 \%$ equity. He also finds no evidence that female-owned or minority-owned firms are less likely to use bank credit, but that Hispanic-owned firms are less likely to use trade credit.

Asiedu, Freeman and Nti-Addae (2012) use data from the 1998 and 2003 SSBFs to analyze credit outcomes for female-owned and minority-owned firms. They conclude from their findings that Black-owned firms faced discrimination in both 1998 and 2003, but worse in 2003; while Hispanic-owned firms faced discrimination in 1998 but not in 2003. They find no evidence of discrimination against firms owned by white females. 
Robb (2013) uses data from the KFS to provide evidence on credit market outcomes during 2007 - 2010 for U.S. start-up firms established during 2004 and that survived until 2007. Consequently, these results are not representative of all small-businesses, just of very young start-up firms that survived their first three years of operations; such firms which face much more difficulty than the typical small business in obtaining credit because of their age and size. Robb studies whether firms applied, whether firms were discouraged, and whether firms that applied were approved or denied credit. She finds that, in all four years, minority-owned firms were significantly more likely to be discouraged from applying when they needed credit and were significantly more likely to be denied credit when they did apply for credit. For femaleowned firms, she finds that they were significantly more likely to be discouraged during the crisis years of $2008-2010$, but were significantly more likely to be denied only during 2008 . It is not possible from these results to extrapolate to the general population of small businesses, but the evidence at least suggests that credit market outcomes were much worse during the crisis years.

Robb and Robinson (2012) use data from the Kauffman Firm Surveys to document that newly founded firms rely heavily on formal debt financing rather than on informal funding from friends and family. They document that, in contrast to the widely-held view about entrepreneurial finance, the largest part of total financial capital comes from outsiders' debt.

\subsection{Hypotheses Development}

Our study extends Robb and Robinson (2012) by providing additional analysis of the use of debt by start-up firms. Our primary hypotheses relate to the differences between firms that use 
credit ("use-credit firms") and firms that use no credit ("no-credit firms"). ${ }^{5}$ We hypothesize that firms using credit at the initial stage of business formation achieve better performance outcomes than firms using no credit at the firm's start-up. This issue is important as prior literature documents that the availability of financing is crucial for the survival and growth of entrepreneurial firms. Furthermore, Robb and Robinson (2012) document that start-up firms choose outside debt as the main source of financial capital. The natural question is whether this choice results in better firm performance outcomes.

Our second set of hypotheses relates to the differences in firm and owner characteristics between use-credit firms and no-credit firms. The pecking-order theory of capital structure suggests that profitable firms, firms with more "financial slack," and firms in certain industries that require little in the way of tangible assets use less debt than other firms. Behavior finance suggests that owners of no-credit firms act irrationally, as these firms are failing to take advantage of either the interest-free financing from typical trade credit terms or the debt-tax shield from bank financing, as well as the opportunity to leverage up their return on equity. The managers of these firms may simply be financially unsophisticated, or may have an irrational aversion to debt of any form and prefer to pay cash for all purchases. We hypothesize that nocredit firms are more likely to be located in rural areas, and have owners with less experience and less education than other types of firms. We also examine whether the primary owner's race or gender determine the firm's use of credit.

\footnotetext{
${ }^{5}$ Robb and Robinson (2012) analyze the amounts of financial capital. Instead, we focus on the incidence of credit use by start-up firms. The analysis of the incidence of credit use is important because of mass points at zero for the amounts of capital. and highly skewed distributions for non-zero use of credit, especially for credit sub-types. This means that the median amount is zero while the mean amount is large and positive for many debt categories.
} 
In all of our analyses, we differentiate between the use of personal and the use of business credit. Specifically, we separate between credit that is used for firms' operations but requires personal guarantees and personal collateral (i.e., credit received based on the personal balance sheet) and credit granted based on the business balance sheet. ${ }^{6}$ Robb and Robinson (2012) presume that "personal guarantees and personal collateral must often be posted to secure financing for startups." However, Avery et al. (1998) report that sixty percent of small business lending is not personally guaranteed. In addition, Avery et al. exclude credit card loans, which account for large portion of KFS business loans. Business credit cards typically are an unsecured form of credit.

Our final set of analysis, distinguishes between the use of credit by corporations and by non-corporations. Cole (2011) shows that liability issues are important at the earliest stage of business formation. We expect that corporations, since they enjoy limited liability, should be more likely to use credit than other forms of business organization. Furthermore, corporations, due to limited liability, should be more likely to use business credit and less likely to use personal credit. Since the owners of other forms of business organizations are personally liable for any debts of the firms, they should be indifferent, from the liability perspective, to pledging personal or business assets and guarantees.

\section{Data and Methodology}

\subsection{Data and Sample Description}

We use data from the Kauffman Firm Survey (KFS) to examine the use of credit by startup firms and the effect of credit use on firm performance and survival. This annual survey

\footnotetext{
${ }^{6}$ KFS does not provide data on the terms of the loans; only whether the loan is business or personal, whether the credit card business or personal, etc.
} 
follows 4,928 privately held firms that were established in 2004. Currently, the survey results are available for the baseline year (2004) and seven follow-up years (2005 - 2011), with the final 2012 results to be released at some time during 2014. The KFS identified start-up firms by using a random sample from Dun \& Bradstreet's database list of new businesses established during 2004, excluding wholly owned subsidiaries of existing businesses, businesses inherited from someone else, not-for-profit organizations, and firms that had any kind of business activity prior to 2004. The KFS represents the largest and the most comprehensive data on U.S. start-up firms. Along with detailed information on the firm's use of credit, the KFS provides data on various firm and owner characteristics. (For more detailed information about the KFS data, see Ballou et al., 2008; and DesRoche et al., 2012).The richness of the KFS data allows us to explore the relation between the use of different types of credit at the firm's start-up and subsequent firm performance and to identify what types of firms use credit and different types of credit at the firm's start-up.

Similar to prior studies using the KFS data, we define a firm's primary owner as the firm's owner who has the highest percentage ownership. ${ }^{7}$ In cases where two or more owners have the same percent ownership, the owner who works the most hours in the firm is defined as the primary owner. In cases where two or more owners report the same ownership and the same number of work hours, a series of other variables (i.e., owner's education, age, work experience, amount of initial equity invested, other start-up experience, and race) is used to create a ranking of owners in order to define the primary owner.

Firm characteristics examined in the study include form of business organization, financial measures, intellectual property, competitive advantage, industry, and ownership

\footnotetext{
${ }^{7}$ See, e.g., Ballou et al. (2008) and Robb et al. (2009). The KFS provides information on the ten largest percentage owners of each firm.
} 
structure. Owner characteristics include age, gender, race, education, prior business and start-up experience of the primary owner, and the number of hours per week the primary owner works in the firm. In many specifications, we also control for other sources of capital, such as, owners' equity, outsider equity, and insider debt. Table 1 provides a summary and definitions of variables used in the study.

Sample descriptive statistics of start-up firms are presented in Table 2. On average, startup firms generated about $\$ 230,000$ in revenues, $\$ 486$ in net income (this is not a typo), and had $\$ 347,000$ in total assets by the end of the first year of operations. The average level of cash and tangible assets was $\$ 38,000$ and $\$ 187,000$, respectively. The financial characteristics of a median firm, however, are quite different from the characteristics of an average firm. The median firm generated only $\$ 7,500$ in revenues, reported a net lost $\$ 300$, had $\$ 20,000$ in total assets, $\$ 2,000$ in cash, and $\$ 5,000$ in tangible assets by the end of the start-up year. The $25^{\text {th }}$ percentile start-up firm had values of zero for revenue, cash, current assets, and tangible assets, and reported a net loss of $\$ 10,000$. The $75^{\text {th }}$ percentile start-up firm had values for revenues and assets that are substantially smaller than the sample averages, indicative of the highly skewed distributions for these financial variables. The table also shows that the standard deviations for firm variables are very large. These observations demonstrate that the distribution of start-up firms is highly skewed with the potential presence of significant outliers. To address the skewness of the distributions, we take the natural logarithms of firm financial characteristics' when creating financial variables for our subsequent analysis.

Table 2 also shows that about one in three start-up firms is organized as a corporation and has more than one owner. At the firm's start-up, the primary owner, on average, is 45 years old, has almost 13 years of prior experience in the same industry, and has one prior start-up 
experience. One in four start-up firms has a female as its primary owner. Four out of five firms have a white primary owner; but less than one in ten have a black primary owner; one in twenty has a primary owner who is Asian or who is Hispanic. With respect to educational attainment, two out of three primary owners have some college education or hold a college (Bachelor's) degree, and one in five holds a graduate degree.

\subsection{Methodology}

In order to provide new evidence on the use of credit by start-up firms, we employ both univariate and multivariate tests. In all of our tests, we incorporate the survey sampling weights because the KFS sample is not a random sample, but, instead, is a stratified random sample where high technology firms are over-represented relative to firms in other industries.

We first explore whether the initial credit conditions (i.e., the use of credit at a firm's start-up) are associated with positive firm outcomes; specifically, survival and growth in terms of revenues. We then examine the distribution of credit use at a firm's start-up. Finally, we analyze what types of firms are more likely to use credit at a firm's start-up. In our analyses, we distinguish between personal and business credit, and between firms with limited personal liability and firms with unlimited personal liability of the firm owners.

\subsubsection{Does Initial Credit Explain Firm Outcomes?}

Robb and Robinson (2012) document that the portion of total capital financed through outsider debt is positively related to the level of revenue, assets, and employment three years after the firm's start-up. Our definition of credit use is different from the variable examined in Robb and Robinson (2012). While Robb and Robinson (2012) focus on the amount of outsider 
debt relative to total capital, we focus on the indicators of credit use, and distinguish between the use of personal and business credit.

Prior studies document that the first few years of firm operations are critical for firm survival. We explore whether the use of credit at the firm's start-up is associated with higher probability of survival during these first critical years. We also explore the relation between the use of credit at the firm's start-up and the level of revenues three years after the firm's establishment. With these performance measures, we are capturing the stability of the firm and its growth during the first critical years. In addition, we test whether the relation between credit use and firm outcomes is different for corporations and non-corporations.

\subsubsection{Survival Analysis}

Although logit models are frequently used in finance to estimate the probability of an event, Shumway (2001) argues that single-period logit models produce biased and inconsistent estimates when dealing with multiple-period data. In contrast, survival functions (e.g., hazard functions) follow the firm through time and observe at which point in time it experiences an event of interest. Another advantage of survival models is that they incorporate data truncation; that is, if some events are unobserved because they occur beyond the end of the sample period, they are taken into consideration through right censoring. While different types of models can be used for survival analysis, the Cox (1972) proportional hazard model is the most popular choice because it does not assume a particular distribution for the probability of survival times; thus, it does not require the exact specification of the baseline hazard function. It is a semi-parametric model that employs a maximum partial likelihood estimation method and has the following form: 


$$
h_{i}(t)=h_{0}(t) \exp \left(X_{i}^{\prime} \beta\right)
$$

where:

$h_{i}(t)$ is the time- $t$ hazard of firm $i(t=2005-2007$ in our analysis $)$;

$h_{0}(t)$ is the baseline hazard function that is left unspecified and corresponds to the probability of an event when all explanatory variables are zero;

$X_{i}$ is a vector of independent variables, which includes Firm Characteristics, Owner

Characteristics, and Other Sources of Capital, corresponding to firm $i$;

$\beta$ is a vector of coefficients to be estimated.

The hazard rate is the probability that firm $i$ will be out of business at the end of year $t$, conditioning on firm $i$ surviving up to time $t$.

\subsubsection{Revenue Analysis}

In our analysis of revenues, we use the level of revenue from 2007 KFS as our dependent variable; and we use credit, firm, owner characteristics, and information about the other sources of capital from 2004 KFS as independent variables. We examine the firm's use of credit in a multivariate framework using the following Weighted-Least-Squares (WLS) regression: Revenue $=\mathrm{f}($ Credit, Firm Characteristics, Owner Characteristics, Other Sources of Capital) where:

Revenue is the dependent variable, measured as the natural logarithm of one plus the level of revenue three years after the firm's start-up; ${ }^{8}$

\footnotetext{
${ }^{8}$ For firms that do not report the amount of 2007 revenues, we use the mid-point value of the reported 2007 revenue range if it is available. Our results do not qualitatively change if we exclude these firms from our analysis. We add one to the level of revenue before taking the natural logarithm to avoid creating a missing value for a firm with zero level of revenues.
} 
Credit indicates whether the firm used any type of credit at the firm's start-up; in the analysis that differentiates the use of personal credit from the use of business credit, the Credit variable is replaced with the indicators Business Credit and Personal Credit; Firm Characteristics is a vector of firm-specific variables, such as credit score, size, form of business organization, intellectual property, competitive advantage, industry; Owner Characteristics is a vector of variables related to the primary owner, such as prior work and start-up experience, the number of hours worked in the firm, age, age ${ }^{2}$, education, race, ethnicity, and gender; and Other Sources of Capital is a vector of variables that indicate whether a firm used trade credit, insider equity, outside equity, or insider debt; it also includes the outsider debt and owners' equity, both scaled by total capital (debt plus equity).

We provide definitions for our variable in Table 1.

\subsubsection{Distribution of Firms by Use of Different Types of Credit at the Firm's Start-Up}

In the next part of our analysis, we examine the distribution of firms by use of credit. A firm is classified as using credit if the firm reported using business, personal, or trade credit in the 2004 survey.

We then differentiate between business and personal credit. A firm is classified as using business credit if the firm reported using credit in any of the following categories: business bank loan, business credit line, business loan from nonbank institutions, business credit card, business credit card issued on owner's name, or business loan from the government, other businesses, or other sources. A firm is classified as using personal credit if the firm reported using credit in any of the following categories: personal bank loan by the primary owner, or by other owners; and 
the primary owner's, or the other owners' use of personal credit cards for business purposes. This classification scheme distinguishes financing through the personal balance sheet of the entrepreneur(s) from financing through the business balance sheet of the firm.

We explore the distribution of firms by use of different types of credit at the firm's startup. We examine the percentage of firms that use credit and different types of credit; the percentage of firms that use only one type of credit; and the percentage of firms that use a combination of credit types. We then examine the differences in credit use and credit types between corporations and non-corporations.

\subsubsection{Factors Explaining the Use of Credit}

In the final part of our analysis, we examine what types of firms are more likely to use credit and different types of credit at the firm's start-up. We first conduct univariate tests for differences in means of various firm and owner characteristics between firms that do, and firms that do not, use credit. For those firms that do use credit, we analyze differences in firm and owner characteristics between firms that use business credit and firms that use personal credit.

In a multivariate analysis, we estimate a bivariate probit model with sample selection. Our selection equation estimates the probability of using credit; in our outcome equation, we estimate the probability of using business (personal) credit, conditional upon using any type of

credit. We use a probit model because our dependent variables are binary and we use a bivariate probit selection model in order to account for a non-random selection mechanism operating on those firms that decide to use credit and choose whether to use business or personal credit. The bivariate probit model consists of two equations

$$
\mathrm{y}_{1}^{*}=\beta_{1}^{\prime} \mathrm{x}_{1}+\epsilon_{1}, \mathrm{y}_{1}=\operatorname{sign}\left(\mathrm{y}_{1}^{*}\right)
$$


and

$$
\mathrm{y}_{2}^{*}=\beta_{2}^{\prime} \mathrm{x}_{2}+\epsilon_{2}, \mathrm{y}_{2}=\operatorname{sign}\left(\mathrm{y}_{2}^{*}\right)
$$

where:

$$
\epsilon_{1}, \epsilon_{2} \sim \text { Bivariate } \operatorname{Normal}(0,0,1,1, \rho)
$$

In the bivariate probit selection model, $\left(\mathrm{y}_{1}, \mathrm{x}_{1}\right)$ are only observed when $\mathrm{y}_{2}$ is equal to one, so the error terms in eq. (3) and eq. (4) must be re-specified as $\epsilon j=\exp (\gamma \mathrm{j}, \mathrm{zj}) \mathrm{uj}$, where (u1, u2) have the bivariate standard normal distribution. The estimated correlation coefficient $\rho$ (the correlation between error terms $\epsilon 1$ and $\epsilon 2$ ) can be used to test for selection bias. If $\rho$ is statistically significant, then we can reject the null hypothesis that selection bias is not present. $X$ is a vector of independent variables as described above in equation (1), and $\beta_{1}, \beta_{2}$ are coefficients to be estimated with Maximum Likelihood Estimation Method.

\section{Data Analysis and Empirical Results}

\subsection{Credit Use and Firm Performance}

In this section, we examine whether the firm's initial capital-structure decisions regarding the use of credit affect firm outcomes during the critical first three years of firm operations. We choose to analyze 2007 revenues and survival, three years after the firm's start-up, in order to facilitate comparisons with the results of Robb and Robinson (2012). We also analyzed revenues for and survival up to 2008, 2009, and 2010, and find that our results are qualitatively unchanged from 2007.9

\subsubsection{Survival}

In Table 3, we present the results from our survival analysis and allude to the idea that firms that use credit at the firm's start-up are more stable, as measured by the hazard rate of

\footnotetext{
${ }^{9}$ These results are not reported in the Tables but are available from the authors upon request.
} 
going out of business. In hazard models, the regression coefficients give the proportional change that can be expected in the log of hazard rate, given the change in explanatory variables. The Table presents hazard ratios, which equal $100^{*}\left(e^{\beta}-1\right)$ and summarizes the economic significance of a given variable.

In column 1 of Table 3 , the coefficient for Credit is a statistically significant 0.848 , which indicates that a firm that uses credit at start-up has about a $15 \%$ lower hazard rate of going out of business; or, alternatively, a $15 \%$ greater survival rate. Furthermore, as shown in column 2 , this relation is driven by the use of business credit; the coefficient for Business Credit is a statistically significant 0.848 , while the coefficient for Personal Credit is not statistically significant in explaining the firm's survival rate.

We sequentially add a vector of firm characteristics, a vector of owner characteristic, and a vector of controls for use of other types of financial capital. Controlling for differences in firm, owner, and other financial capital characteristics (columns 3, 4 and 5), we find that the coefficient of Business Credit is statistically significant at better than the 0.01 level, and its level falls to $0.77-0.80$, indicating that a firm obtaining business credit at start-up has a $20 \%-23 \%$ higher survival rate than does a firm unable to obtain such financing. As shown in column 5, Business Credit is the only significant capital-structure variable.

Reviewing our control variables in columns 3-5, we find that several are consistently significant at the 0.10 level or better. Firms with intellectual property, firms that provide product and service, firms with older owners, firms with better educated owners, and firms whose owners have greater prior experience in the same industry are less likely to fail. In contrast, firms that provide product only, and firms whose owners have a higher number of prior start-ups are more likely to go out of business. 
In column 6 of Table 3, we replace Business Credit, Personal Credit, and the indicator variable Corp with a set of four interaction terms, where we multiply both Business Credit and Personal Credit by the indicator variables Corp and Non-Corp. This enables us to decompose the impact of business and personal credit into the components contributed by Corps and NonCorps. In column 6, we find that the coefficient on Business Credit*Non-Corp is a statistically significant 0.639 , indicating that Non-Corps obtaining business credit at start-up have a $36 \%$ higher survival rate. This is consistent with the signalling argument that firms able to obtain credit in the name of the firm are of higher quality.

The analysis presented in Table 3 shows that firms that use credit, specifically business credit, at the firm's start-up are more likely to survive during three years after the start-up. The analysis, however, does not indicate whether the higher survival rate of credit-users is due to the credit provider's ability to choose more successful firms or due to the fact that the availability of credit helps firms to be more successful. In column 7 we address this issue by comparing the survival rates of credit users to the survival rates of comparable firms that do not use credit at start-up. We use the propensity score matching to identify firms that are similar across three characteristics: credit risk, 2004 level of revenue (ln(revenue+1)), and 2004 level of total assets $(\ln ($ total assets +1$)$. Results show that the positive effect of the use of business credit on the firm's survival rate remains strong and significant in both economic and statistical terms in the matched sample of firms. This suggests that the availability of credit capital, especially business credit capital, helps firms to become more successful in terms of their survival rate. 


\subsubsection{Revenues}

Table 4 presents the results from our analysis of 2007 revenues. Column 1 shows that the use of credit at the firm's start-up in 2004 is associated with higher levels of revenue in 2007, three years after the firm's start-up. When Credit is decomposed into its components of Business Credit and Personal Credit (column 2), we find that the business credit drives the positive relation between 2004 credit use and the level of 2007 revenues.

In columns $3-5$, we sequentially add a vector of firm characteristics, a vector of owner characteristic, and a vector of controls for use of other types of financial capital. Controlling for differences in firm and owner characteristics (columns 3 and 4), we find that the use of business credit is positively and significantly related to 2007 revenues, while the use of personal credit is negatively and significantly related to 2007 revenues. Furthermore, as shown in column 5, we find that the indicators for 2004 use of trade credit and outsider equity both are positively and significantly related to the level of 2007 revenues, while the indicator of insider equity (i.e., equity provided by spouse or family members) is negatively and significantly related to 2007 revenues. The outsider debt variable used in Robb and Robinson (2012) (Outsiders' Debt/Totcap) is not significant.

In column 6 of Table 4, we replace our Business Credit and Personal Credit variables with interaction terms that multiply these two variables by our indicators for Corps and NonCorps. This enables us to test whether our results are being driven by limited liability firms. As shown in column 6, we find that the coefficient on interaction term Business Credit ${ }^{*}$ Corp is positive and significant, indicating that corporations using business credit at the firm's start-up perform better than corporations that do not use credit at the firm's start-up. However, for NonCorps, there is no significant difference in performance between those that do, and do not, use 
business credit. Furthermore, we find that Corps using personal credit at start-up perform worse than do Corps that do not rely of personal credit at start-up.

In column 7, we analyze the relation between the firm's use of credit and the level of revenue three years after the start-up for the sample of firms matched on credit risk, level of revenues and total assets using propensity score matching as in Table 3, column 7. Results for the matched sample of firms also show the positive effect of the use of business credit on the level of revenue suggesting that the availability of business credit financing helps firms to grow faster.

Overall, the results presented in Table 4 show that the use of credit at the firm's start-up provides information about future firm performance. Furthermore, the relation between credit use and firm performance varies depending on the type of credit. One possible explanation is that the ability of a firm to secure business and trade credit at the firm's start-up makes the firm less capital constrained and, hence, allows it to grow faster than firms that cannot obtain such financing (see, e.g., King and Levine, 1993a, 1993b; Rajan and Zingales, 1998). Another possible explanation is that firms obtaining business and trade credit at start-up are of better quality than firms without such start-up financing. In other words, lenders assess that these firms have better prospects and, hence, are willing to provide credit. Use of business credit and trade credit at start-up is simply a signal for higher quality firms. This line of reasoning would explain why the use of personal credit is negatively associated with revenue level: firms that are not able to secure financing backed only by the firm's balance sheet (i.e., business credit and trade credit) due to poorer future prospects are forced to rely on personal types of credit. Alternatively, the negative coefficient on Personal Credit could indicate that the owners of firms that use personal 
credit at the firm's start-up are more "conservative" due to a levered equity position in the firm and prefer slower revenue growth than do less conservative firms.

In addition, Table 4 shows that firms with higher level of 2004 revenues have higher 2007 revenues. Corps, firms with competitive advantage, and firms that provide product and service have higher revenue three years after the firm's start-up. However, firms owned by female, black or Hispanic owners have a lower 2007 revenue. Whereas hours worked in the firm by the primary owner is positively related to 2007 revenues.

\subsection{Use of Credit at the Firm's Start-Up}

In this section, we examine the use of credit by start-up firms and compare the use of credit between firms with limited personal liability of the firm's owners and firms with unlimited personal liability. Firms with limited personal liability are labeled as Corps and include firms that are organized as C-corporations, S-corporations, or limited-liability companies or partnerships (LLC/LLP). Firms with unlimited personal liability are labeled as Non-Corps and include firms that are organized as sole proprietorships or partnerships. In our sample, $30 \%$ of the firms are classified as Corps and 70\% as Non-Corps (see Table 2).

Table 5 reports the percentage of firms that use different types of credit at start-up, based upon data from initial 2004 Kauffman Firm Survey. Column 2 reports results for the full sample, whereas columns 3 and 4 present results separately for Corps and Non-Corps. Column 5 presents the results of a test for significant differences in proportions of Corps vs. Non-Corps. Panel A presents the distribution of credit use for the entire KFS 2004 sample, whereas Panels B and C limit the analysis to firms that report using any form of credit (i.e., excludes firms that report zero use of credit). Among firms that use credit, Panel B presents the percentage of firms that use 
a single type of credit, while Panel $\mathrm{C}$ reports the percentage of firms that use various combinations of credit types.

As reported in Panel A, 76\% of firms use some type of credit at the firm's start-up. This is quite similar to $80 \%$ of closely held U.S. firms of any age documented by Cole (2010), which suggests that entrepreneurial firms try to secure credit financing at the earliest stage of their formation. This finding compliments those of Robb and Robinson (2012), who report that a large portion of total start-up capital is financed by outsider debt. We show that three out of four firms use some type of formal credit financing, in addition, or instead of, relying entirely upon equity and insiders' (informal) debt.

The analysis of different credit categories shows that $24 \%$ of firms use trade credit, $44 \%$ use business credit, and 55\% use personal credit. This shows that over half of start-up firms' owners explicitly take on personal liabilities beyond their investments in their firm in order to secure financing for their new business ventures, consistent with Robb and Robinson's (2012) statement that many entrepreneurs hold levered equity stakes in their ventures. However, a sizable fraction of start-up firms secure financing in the name of the business itself. While it is possible that business credit is backed by personal guarantees and personal collateral, the fact that a majority of start-ups explicitly uses personal credit, while a significant minority uses business credit suggests that there are important differences in these firms and in their capitalstructure decisions. ${ }^{10}$

The break-out of business credit and personal credit into finer categories shows that personal credit cards of the primary owner is the most common credit type used (46\%), followed by business credit cards (over 25\%). The results show that a smaller percentage of firms rely on

\footnotetext{
${ }^{10}$ The KFS does not provide data on personal guarantees or personal wealth of the entrepreneurs in 2004 so we cannot directly test this proposition.
} 
bank credit: only about $20 \%$ of start-ups use personal bank loans taken out by an owner, only $9 \%$ use business credit lines, and only 7\% use business bank loans. Our analysis complements that of Robb and Robinson (2012); they focus on the amounts of outsiders' debt, whereas we focus on the incidence of credit use and on the distinction between business vs. personal credit.

Our findings provide some important insights that contribute to the literature on credit use by start-up firms. For example, while Robb and Robinson (2012) show that the amount of credit card balance is small relative to other sources of funds, we document that start-up firms rely on credit cards more often than on any other type of credit financing. Alternatively, while nonbank business loans and government business loans are large in size (see Table 4 in Robb and Robinson, 2012), extremely few firms (less than 1\%) receive either of these types of financing at start-up.

The results in Panels B and C, which exclude firms that do not use credit, closely resemble the results presented in Panel A, which includes all firms. Only 5.5\% rely exclusively on trade credit, whereas $28.7 \%$ rely exclusively on personal credit and $16.3 \%$ rely exclusively on business credit. Panel C shows the portion of firms relying upon multiple types of credit: $36.1 \%$ use both personal and business credit, almost $40 \%$ use a combination of trade credit with either business $(18.4 \%)$ or personal credit $(19.8 \%)$, and $12.4 \%$ rely on all three types of credit In addition to the analysis of credit use by all firms, Table 5 compares the incidence of credit use for Corps and Non-Corps. One of the main differences is that the owners of Corps face only limited personal liability for firms' debts, while the owners of Non-Corps face unlimited personal liability for their firms' debts. Our results provide some interesting insights. First, use of credit is significantly higher at Corps $(80 \%)$ than at Non-Corps (71\%). While this difference could be explained by greater demand or better supply of credit for corporations than for other 
business forms, it also is consistent with the notion that the owners of corporations who do not face personal liability are more likely to use credit, and, in particular, business credit.

In fact, Panel A of Table 5 also shows that use of business credit, but not personal credit, is significantly higher at Corps than at Non-Corps: $51 \%$ vs. $35 \%$ for business credit but $56 \%$ vs. $54 \%$ for personal credit. These results strongly suggest that personal liability is very important for owners of start-up firms and that, consequently, owners of Corps who enjoy limited personal liability, are more likely to choose to use business debt in their firm's capital structure.

Panel A of Table 5 also shows that personal credit is the most often used type of credit at the firm's start-up, even for Corps. Moreover, Panels B and C of Table 3 report that Corps, compared to Non-Corps, are less likely to rely entirely upon personal credit as the sole credit category ( $24 \%$ vs. $37 \%$ ), and are more likely to use all three types of credit (14\% vs. $10 \%)$. Analysis of more narrow credit categories in presented in Panel A shows that corporations are more likely to use almost any type of credit: business credit cards and credit lines, business and personal bank loans.

\subsection{The Determinants of Credit Use}

\subsubsection{Univariate Analysis}

Table 6 presents univariate analysis of the differences in firm and owner characteristics between start-up firms that use credit ("use-credit firms") and start-up firms that do not use credit ("no-credit firms"). Data are from the 2004 KFS. Panel A examines the differences in the full sample between firms that use credit and firms that do not use credit. Panels B and C limit the analysis to firms that use credit; Panel B analyzes the differences between firms that use and do not use business credit, while Panel C analyzes firms that use and do not use personal credit. In 
each of the three panels, columns 1 and 3 present mean values of the variables for firms that do, and do not, use that type of credit, respectively; column 3 presents $p$-values for a $t$-test of significant differences in means of shown in columns 2 and 3; and column 4 shows the number of non-missing observations for that variable.

Overall, our results in Table 6 show highly significant differences in the means of firm and principal owner's characteristics for firms that do, and do not, borrow at the start-up. In terms of both revenues and total assets, business borrowers are significantly larger and more likely to be organized as Corps, whereas personal borrowers are significantly smaller and less likely to be organized as Corps. Using data on privately held firms of all ages from the SSBFs, Cole (2010) also documents that borrowers are larger than are non-borrowers. These results are consistent with the premise that entrepreneurs choose to organize the business as a corporation in order to avoid the unlimited personal liability of sole proprietorships and partnerships. If the liability issue is an important factor in choosing the form of business organization, then it is not surprising that corporations try to avoid the form of debt that carries the largest personal liability, i.e., personal debt.

Firms that use business credit have higher business credit scores, whereas firms that use personal credit have lower business credit scores. This suggests that it is more difficult for firms with higher credit risk to raise funds without personal guarantees.

Finally, firms that use business credit are more likely, whereas firms that use personal credit are less likely, to have multiple owners. There are a number of potential explanations for this: for example, owners might want to avoid unlimited liability from personal borrowing when they have only a portion of residual cash-flow rights; and multiple owners provide access to the equity beyond the personal wealth of the primary owner, and this equity is a substitute for 
personal borrowing that entails unlimited liability; multiple owners complicate the underwriting of personal loan, especially if business collateral is involved. It also may be that the owner of a single-owner firm decides to borrow on personal account to cover business-related expenses so that she can avoid having to share residual cash-flow rights with other equity holders.

Table 6 also shows that use-credit firms and no-credit firms exhibit significant differences in the characteristics of the principal owner. Among firms that use business credit, the primary owner is less likely to be female or black, whereas, among firms that use personal credit, the primary owner is more likely to be female. These results complement prior findings that small firms owned by minorities experience more difficulties in obtaining financing than firms owned by non-minorities. (See, e.g., Coleman, 2002; Blanchflower et al., 2003; Cole, 2009; Coleman and Robb, 2009; Fairlie and Robb, 2009; Robb and Watson, 2011).

Finally, Table 6 illustrates that the primary owner's education and work experience may affect the use of credit at the firm's start-up. Firms that use business credit are more likely to have owners with graduate degrees; and firms that use personal credit have owners with less experience in the same industry.

\subsubsection{Multivariate Analysis}

In Table 7, we move to multivariate analysis, utilizing a weighted bivariate probit regression model with sample selection to examine the firm's decision to use credit. In the first stage of the bivariate probit model (column 2), the dependent variable takes a value of one if the

firm uses any type of credit and takes on a value of zero otherwise. Conditional upon using credit in the first stage, the second stage simultaneously estimates the probability of using business 
credit/personal credit; the results of this analysis appear in columns 3 and 4, respectively. In each of the four columns, we report odds ratios over $t$-statistics (in parentheses).

As shown in column 2 of Table 7, firms that use credit are significantly larger as measured by both revenues and assets. The economic significance of these variables is four percent higher odds of using credit for one percent increase in revenues, and an almost six percent increase in the odds of using credit for one percent assets. ${ }^{11}$ In general, corporations are $16 \%$ more likely to use credit than other forms of business organizations combined. Furthermore, firms with greater credit risk are less likely to borrow at the start-up. A one-step decrease in the firm's credit category is associated with $13 \%$ lower odds of obtaining credit. Firms with competitive advantage are $15 \%$ more likely to use credit. Firms that provide product only are $38.5 \%$ more likely to use credit, while firms that provide products and service are $19 \%$ less likely to use credit.

Table 7 also shows that several owner characteristics significantly relate to the probability of using credit at the firm's start-up. Firms with owners who have more experience in the same industry are less likely to borrow funds; but the effect is not economically significant. Corps are $15 \%$ more likely to borrow than Non-Corps, which is consistent with the limited liability afforded to business loans. Firms with worse business credit scores are significantly less likely to borrow, with the odds declining by $11 \%$ for each increment in the categorical credit score. Firms reporting that they have a competitive advantage are $15 \%$ more likely to borrow than other firms without advantage. Firms that only produce a product are almost $40 \%$ more likely to borrow than other firms and firms that produce both a product and a service are almost $20 \%$ less likely to borrow than other firms.

\footnotetext{
${ }^{11}$ We add one to cash and revenue in order to avoid creation of missing values when we perform logarithmic transformations on those variables.
} 
Firms with owners who are college educated are $20 \%$ more likely to borrow, while firms with owners who have a graduate degree are almost $60 \%$ more likely to borrow. Consistent with prior studies documenting lower availability of credit to minorities, our results show that firms with Black owners are more than $40 \%$ less likely to use credit at start-up. Finally, firms with higher owners' equity and firms with the contribution of insider equity are more likely to use credit at the start-up.

In columns 3 and 4, we present the results from the second stage of the selection model, which estimate the probability of using business credit or personal credit, respectively, conditional upon using any type of credit. These results document notable differences between firms that use these two different sources of credit.

Firms that are larger in terms of revenues generated by the end of the start-up year are more likely to use business credit, but are less likely to use personal credit. Firms reporting more assets are more likely to use business, but not personal, credit. Corporations are 34\% more likely to use business credit, but are no more likely to use personal, credit. Firms that have multiple owners are almost $20 \%$ less likely to use personal credit, but no more likely to use business credit. Firms with worse credit scores are significantly less likely to use business credit and significantly more likely to use personal credit.

Our results also show that owner characteristics have significant effects on the probability of using a given type of credit. Firms that are owned by females are 18\% more likely to use personal credit, but are no less likely to use business credit. Firms with highly educated owners are $20 \%$ likely to use business credit, but no less likely to use personal credit. Firms with Black owners are more than $30 \%$ less likely to use business credit, but no more likely to use personal 
credit. Firms that report using insider debt are almost $20 \%$ less likely to use business debt and almost $30 \%$ more likely to use personal debt.

\section{Summary and Conclusion}

In this study, we use data from the Kauffman Firm Survey to provide new evidence on how U.S. start-up firms choose their initial capital structure and why this decision is important. Seventy five percent of firms use some type of credit at the firm's start-up. First, we analyze what factors explain whether or not a firm uses credit in its initial capital structure; and, if so, what types of credit it uses (business or personal). We establish that the initial capital structure decision is important because it influence future outcomes in terms of survival and growth. Firms that use debt in their initial capital structure, and, in particular, firms that use business debt rather than personal debt, are significantly more likely to survive their first three years of operations and, if they survive, have significantly higher revenues.

We find that firms are more likely to use credit at start-up when they are larger in terms of revenues, have more assets, are organized as corporations, and have lower credit risk. Firms with competitive advantage and that provide product only are more likely to use credit, while firms that provide product and service are less likely to use credit. Firms with more educated primary owners are more likely to use credit. Black-owned firms are significantly less likely to use credit at start-up. Among firms that use credit, we find that larger firms are more likely to use business credit but less likely to use personal credit; firms with more assets are more likely to use business credit; firms with better credit scores are more likely to use business credit but less likely to use personal credit; corporations are more likely to use business credit; firms with multiple owners are less likely to use personal credit; black owners are less likely to use business 
credit; and firms with owners who work more hours in the firm are more likely to use business credit.

Our study contributes, in several important ways, to both the entrepreneurship and finance literatures. First, we contribute to the growing literature that analyzes data from the Kauffman Firm Survey by presenting new evidence on the use of credit by start-up firms.

Second, we contribute to the strand of the capital-structure literature that focuses on privately held firms by providing new evidence on the mix of credit upon which privately held firms rely at start-up. Finally, we provide new evidence to the growing literature on zero-debt firms. We document that about $25 \%$ of start-up firms are financed exclusively with owners' equity. 


\section{References}

Ang, J., 1992, On the theory of finance for privately held firms, Journal of Small Business Finance 1, 185-203.

Ang, J., Cole, R., and Lin, J., 2000, Agency costs and ownership structure, The Journal of Finance 55, 81-106.

Ang, J., Cole, R., and Lawson, J., 2010, The role of owner in capital structure decisions: An analysis of single-owner corporations, Journal of Entrepreneurial Finance 14, 1-36.

Avery, R., Bostic, R., and Samolyk, K., 1998, The role of personal wealth in small business finance, Journal of Banking and Finance 22, 1019-1061.

Ballou, J., T. Barton, D. Des Rouches, F. Potter, E.J. Reedy, A. Robb, S. Shane, and Z. Zhao, 2008, Kauffman Firm Survey: Results from the Baseline and First Follow-Up Surveys. Available at: http://ssrn.com/abstract=1024045.

Berger, A., and Udell, G., 1998, The economics of small business finance: The roles of private equity and debt markets in the financial growth cycle, Journal of Banking and Finance 22, 613673.

Blanchflower, D., Levine, P., and Zimmerman, D., 2003, Discrimination in the small business credit market, Review of Economics and Statistics 84, 930-943.

Brav, O., 2009, Access to capital, capital structure, and the funding of the firm, The Journal of Finance 64, 263-308.

Brealey, R., Myers, S., and Allen, F., 2011. Principles of corporate finance. McGraw-Hill. ISBN 0078034760 .

Burkart, M., and Ellingsen, T., 2004, In-kind finance: A theory of trade credit, American Economic Review 9, 569-590.

Cassar, G., 2004, The financing of business start-ups, Journal of Business Venturing 19, 261283.

Claessens, S., Djankov, S., and Lang, L., 2000, The separation of ownership and control in East Asian corporations, The Journal of Finance 58, 81-112.

Cole, R, 1998, The importance of relationships to the availability of credit, Journal of Banking \& Finance 22, 959-997.

Cole, R, 2008, What do we know about the capital structure of privately held firms? Evidence from the Surveys of Small Business Finances, U.S. Small Business Administration Research Study No. 324. 
Cole, R., 2009, Who needs credit and who gets credit? Evidence from the Surveys of Small Business Finances, In Small Business in Focus: Finance. A Compendium of Research by the Small Business Administration Office of Advocacy, July, 95-133.

Cole, R., 2010, Bank credit, trade credit or no credit? Evidence from the Surveys of Small Business Finances, U.S. Small Business Administration Research Study No. 365.

Cole, R., 2011, How do firms choose legal form of organization? U.S. Small Business Administration Research Study No. 383.

Cole, R, 2013, What do we know about the capital structure of privately held firms? Evidence from the Surveys of Small Business Finances, Financial Management (Winter), 777-813.

Coleman, S., 2002, The borrowing experience of black and Hispanic-owned small firms: Evidence from the 1998 Survey of Small Business Finances, The Academy of Entrepreneurship Journal 8, 1-20.

Coleman, S. and Robb, A., 2009, A comparison of new firm financing by gender: Evidence from the Kauffman Firm Survey data, Small Business Economics 33, 397-411.

Coleman, S. and Robb, A., 2011, Capital structure theory and new technology firms: Is there a match? Management Research Review, forthcoming.

DesRoches, D., Potter, F, Santos, B, Sengmavong, A, Zheng, Y., 2012. Kauffman Firm Survey (KFS) sixth follow up methodology report. Available at: http://ssrn.com/abstract=2027044.

Fairlie, R. and Robb, A., 2009, Gender differences in business performance: Evidence from the characteristics of business owners survey, Small Business Economics 33, 375-395.

Ferris, J., 1981, A transaction theory of trade credit use, Quarterly Journal of Economics 94, 243-270.

Fisman, R. and Love, I., 2003, Trade credit, financial intermediation and industry growth, The Journal of Finance 58, 353-374.

Giannetti, M., Burkhart, M., and Ellingsen, T., 2011, What you sell is what you lend? Explaining trade credit contracts, Review of Financial Studies 24, 1261-1298.

Haltiwanger, J., Jarmin, R. and Miranda, J., 2010, Who creates jobs? Small vs. large vs. young, NBER Working Paper No. 16300.

Harris, M. and Raviv, A., 1991, The theory of capital structure, The Journal of Finance 46, 297355.

Heckman, J., 1979, Sample selection bias as a specification error, Econometrica 47, 153-161. 
Huyghebaert, N., Van de Gucht, L. and Van Hulle, C., 2007, The choice between bank debt and trade credit in business start-ups, Small Business Economics 29, 435-452.

Jensen, M., and Meckling, W., 1976, Theory of the firm: Managerial behavior agency costs and capital structure, Journal of Financial Economics 3, 305-360.

Kraus A., and R.H. Litzenberger, 1973, A state-preference model of optimal financial leverage, The Journal of Finance, 911-922.

Meltzer, A., 1960, Mercantile credit, monetary policy and the size of firms, Review of Economics and Statistics 42, 429-436.

Mian, S., and Smith, C., 1992, Accounts receivable management policy: Theory and evidence, The Journal of Finance 47, 169-200.

Myers, S., 1984, The capital structure puzzle, The Journal of Finance 39, 575-592.

Nilsen, J, 2002, Trade credit and the bank lending channel, Journal of Money, Credit \& Banking 34, 226-253.

Petersen, M., and Rajan, R., 1994, The benefits of lending relationships: Evidence from small business data, The Journal of Finance 46, 3-37.

Petersen, M., and Rajan, R., 1997, Trade credit: Theories and evidence, Review of Financial Studies 10, 661-691.

Robb, A.M., R. Fairlie, and D.T. Robinson, 2009, Financial capital injections among new black and white business ventures: Evidence from the Kauffman Firm Survey, working paper.

Robb, A.M. and D.T. Robinson, 2012, The capital structure decisions of new firms, Review of Financial Studies, doi: 10.1093/rfs/hhs072, forthcoming.

Robb, A.M., and J. Watson, 2011, Gender differences in firm performance: Evidence from new ventures in the United States, Journal of Business Venturing, forthcoming.

Ross, S., Westerfield, R., and J. Jaffe., 2012, Corporate Finance $10^{\text {th }}$ Edition. McGraw Hill. ISBN 0077511387

Smith, J., 1987, Trade credit and informational asymmetry, The Journal of Finance 42, 863-872.

Schwienbacher, A., 2013, The entrepreneur's investor choice: The impact on later-stage firm development, Journal of Business Venturing 28: 528-545 


\section{Table 1 \\ Variable Definitions}

All variables, unless indicated otherwise, are from the 2004 Kauffman Firm Survey.

Credit Variables:

Credit

Dummy variable, equals 1 if firm reports that it used either trade credit, business credit, or personal credit.

Business Credit

Dummy variable, equals 1 if firm reports that it used business credit. Business credit includes either of the following categories: business bank loan, business credit line, business loan from nonbank institutions, business credit card, business credit card issued on owner's name, business loan from the government, business loan from other businesses, business loan from other sources.

Personal Credit

Dummy variable, equals 1 if firm reports that it used personal credit. Personal credit includes either of the following categories: personal bank loan by the primary owner, personal bank loan by other owners, the primary owner's personal credit card used for business purposes, and the other owners' personal credit cards used for business purposes.

Other Sources of Capital:

Trade Credit

Dummy variable, equals 1 if firm reports that it used trade credit.

Outsider Debt/Total Capital

Outsider debt, divided by total financial capital (debt + equity). Outsider debt is as defined in Robb and Robinson (2012) and is the sum of balances of the following sources of capital: personal bank loan by the primary owner, personal bank loan by other owners, business bank loan, business credit line, business loan from nonbank institutions, business credit card, business credit card issued on owner's name, business loan from the government, business loan from other businesses, business loan from other sources, other individual loans.

Owners' Equity/Total Capital Total equity invested by all owners, divided by total financial capital (debt + equity).

Insider Equity

Dummy variable, equals 1 if either spouse or parent provided equity financing.

Insider Debt

Dummy variable, equals 1 if either family, employee, or any firm owner loaned money to the firm, primary owner, or other owners.

Outsider Equity

Dummy variable, equals 1 if informal investors (i.e., angel investors), businesses, government, venture capitalists, or other entities provided equity financing. 


\section{Firm Characteristics:}

Revenue

Total Assets

Net Income

ROA

Cash

Current Assets

Tangible Assets

Credit Risk

Corp

Non-Corp

Multiown

Intell Property

Comp Advantage

Product

Product \& Service

Urban

\section{Owner Characteristics:}

Primary Owner

Ownership

Owner Age

Female

Asian

Black

Hispanic

White

Other Race

High School

College Education

Graduate Degree

Prior Experience

Prior Start-ups

Hours worked
Annual revenue from sales of product or service.

Total assets (sum of cash, current assets, and tangible assets)

Annual profit or loss (profit positive, loss negative)

Net income / total assets

Cash

Sum of accounts receivable and inventory

Sum of equipment, land/building, vehicles, other business property, and other assets such as intangibles

Categorical variable (1 to 5) based on the credit score of the firm derived from Dunn and Bradstreet U.S. Ratings and Scores. A firm with a credit risk of 1 has the highest credit quality; a firm with a credit risk of 5 has the lowest credit quality.

Firm is organized as an S-corporation, C-corporation, or Limited

Liability Company/Partnership (LLC/LLP)

Firm is organized as a Sole-proprietorship or Partnership

Firm has more than one owner

Dummy variable, equals 1 if firm reports that it has trademarks, patents, or copyrights.

Dummy variable, equals 1 if firm reports that it has a comparative advantage.

Dummy variable, equals 1 if firm only sells product.

Dummy variable, equals 1 if firm sells product and service

Dummy variable, equals 1 if business location is in a metropolitan statistical area (MSA).

Owner with the highest percentage of firm ownership

Firm ownership (in \%) by primary owner

Age of primary owner (in years)

Primary owner is female

Primary owner is Asian

Primary owner is Black

Primary owner is Hispanic

Primary owner is White

Primary owner is other than White, Asian, Hispanic, or Black

Primary owner is either a high school graduate, has some high school education but no diploma, or has less than $9^{\text {th }}$ grade education

Primary owner has either attended some college, has a Bachelor's degree or may have attended a graduate school but has no graduate degree

Primary owner has a graduate degree (Master's, Professional school, or Doctorate)

Prior work experience (in years) of the primary owner in the same industry

Number of prior business start-ups by the primary owner

Number of hours worked per week by the primary owner 
Industry Classifications:

Agriculture, Forestry, Fishing and Hunting

Mining and Utilities

Construction

Manufacturing

Wholesale Trade

Retail Trade

Transportation and Warehousing

Information

Finance and Insurance

Real Estate and Rental and Leasing

Professional, Management, and Educational Services

Administrative and Support and Waste Management and Remediation Services

Health Care and Social Assistance

Arts, Entertainment, and Recreation

Accommodation and Food Services

Other Services, including Public Administration
Two-Digit NAICS Code

11

21,22

23

31-33

42

44-45

$48-49$

51

52

53

$54,55,61$

56

62

71

72

81,92 
Table 2

\section{Descriptive Statistics of Start-up Firms}

The sample includes Kauffman Firm Survey 2004 start-up firms. Variable definitions are provided in Table 1. For each variable, the table presents the $25^{\text {th }}$ percentile value, the mean, the median, the $75^{\text {th }}$ percentile value, the standard deviation and the number of nonmissing observations $N$.

(continues) 
Table 2 (continued)

\begin{tabular}{|c|c|c|c|c|c|c|}
\hline \multirow[b]{2}{*}{ Variable } & & \multirow[b]{2}{*}{ Standard Deviation } & \multirow[b]{2}{*}{$\mathrm{N}$} \\
\hline & $25^{\text {th }}$ Percentile & Mean & Median & $75^{\text {th }}$ Percentile & & \\
\hline \multicolumn{7}{|l|}{ Firm Characteristics: } \\
\hline Revenue (\$) & 0 & 229,789 & 7,500 & 62,500 & $5,526,475$ & 4,741 \\
\hline Net Income (\$) & $-10,000$ & 486 & -300 & 5,000 & 437,137 & 4,586 \\
\hline Total Assets (\$) & 3,400 & 347,177 & 20,000 & 76,000 & $5,642,656$ & 4,818 \\
\hline ROA & -0.44 & -20.69 & -0.03 & 0.24 & $1,308.23$ & 4,123 \\
\hline Cash (\$) & 0 & 37,682 & 2,000 & 10,000 & 413,690 & 4,680 \\
\hline Current Assets (\$) & 0 & 125,983 & 1,000 & 15,000 & $4,500,293$ & 4,755 \\
\hline Tangible Assets (\$) & 0 & 186,548 & 5,000 & 29,000 & $2,717,975$ & 4,810 \\
\hline Corp & 0.00 & 0.62 & 1.00 & 1.00 & 0.49 & 4,928 \\
\hline Credit Risk & 3.00 & 3.40 & 3.00 & 4.00 & 0.72 & 3,606 \\
\hline Rural & 0.00 & 0.17 & 0.00 & 0.00 & 0.37 & 4,928 \\
\hline Multiown & 0.00 & 0.36 & 0.00 & 1.00 & 0.48 & 4,923 \\
\hline Ownership & 50.00 & 80.49 & 100.00 & 100.00 & 27.37 & 4,880 \\
\hline Comp Advantage & 0.00 & 0.65 & 1.00 & 1.00 & 0.48 & 4,858 \\
\hline Product & 0.00 & 0.52 & 1.00 & 1.00 & 0.50 & 4,928 \\
\hline Product \& Service & 0.00 & 0.37 & 0.00 & 1.00 & 0.48 & 4,928 \\
\hline \multicolumn{7}{|c|}{ Primary Owner Characteristics: } \\
\hline Owner Age & 37.00 & 44.99 & 44.00 & 53.00 & 10.88 & 4,860 \\
\hline Hours Worked & 20.00 & 42.25 & 45.00 & 60.00 & 23.96 & 4,825 \\
\hline Prior Experience & 3.00 & 12.84 & 10.00 & 20.00 & 10.71 & 4,907 \\
\hline Prior Start-ups & 0.00 & 1.02 & 0.00 & 1.00 & 3.17 & 4,893 \\
\hline Female & 0.00 & 0.26 & 0.00 & 1.00 & 0.44 & 4,920 \\
\hline Asian & 0.00 & 0.05 & 0.00 & 0.00 & 0.21 & 4,888 \\
\hline Black & 0.00 & 0.08 & 0.00 & 0.00 & 0.28 & 4,888 \\
\hline Hispanic & 0.00 & 0.05 & 0.00 & 0.00 & 0.23 & 4,888 \\
\hline White & 1.00 & 0.79 & 1.00 & 1.00 & 0.41 & 4,888 \\
\hline Other Race & 0.00 & 0.03 & 0.00 & 0.00 & 0.16 & 4,888 \\
\hline High School & 0.00 & 0.12 & 0.00 & 0.00 & 0.33 & 4,895 \\
\hline College Education & 0.00 & 0.66 & 1.00 & 1.00 & 0.47 & 4,895 \\
\hline Graduate Degree & 0.00 & 0.21 & 0.00 & 0.00 & 0.41 & 4,895 \\
\hline
\end{tabular}


Table 3

Credit Use and Firm Performance: Survival Analysis

The table reports hazard ratios from the Cox proportional hazard model. The dependent variable is the probability that firm $i$ will be out of business at the end of year $t$, conditioning on firm $i$ surviving up to time $(t=2005-2007)$. Independent variables are from KFS 2004 and are described in Table 1. Industry dummies are included in all regressions. Column 7 presents the results from the propensity score matched sample. $N$ is the number of observations. $z$-statistics are reported in parentheses. Survey weights applied. $* * *, * *$, and $*$ indicate statistical significance at the $1 \%, 5 \%$, and $10 \%$ level, respectively.

\begin{tabular}{|c|c|c|c|c|c|c|c|}
\hline Variables & 1 & 2 & 3 & 4 & 5 & 6 & 7 \\
\hline Credit & $\begin{array}{l}0.848 \\
(-2.26) * *\end{array}$ & & & & & & \\
\hline Business Credit & & $\begin{array}{l}0.848 \\
(-2.51)^{* *}\end{array}$ & $\begin{array}{l}0.768 \\
(-3.29) * * *\end{array}$ & $\begin{array}{l}0.799 \\
(-2.72)^{* * *}\end{array}$ & $\begin{array}{l}0.783 \\
(-2.68) * * *\end{array}$ & & $\begin{array}{l}0.683 \\
(-2.34)^{* *}\end{array}$ \\
\hline Personal Credit & & $\begin{array}{l}1.043 \\
(0.64)\end{array}$ & $\begin{array}{l}1.102 \\
(1.24)\end{array}$ & $\begin{array}{l}1.078 \\
(0.92)\end{array}$ & $\begin{array}{l}1.026 \\
(0.29)\end{array}$ & & $\begin{array}{l}0.930 \\
(-0.47)\end{array}$ \\
\hline \multicolumn{8}{|l|}{ Firm Characteristics: } \\
\hline Ln (Revenue 2004 +1) & & & $\begin{array}{l}0.993 \\
(-0.89)\end{array}$ & $\begin{array}{l}0.999 \\
(-0.14)\end{array}$ & $\begin{array}{l}0.996 \\
(-0.46)\end{array}$ & $\begin{array}{l}0.996 \\
(-0.47)\end{array}$ & $\begin{array}{l}1.004 \\
(0.31)\end{array}$ \\
\hline Corp & & & $\begin{array}{l}1.110 \\
(1.16)\end{array}$ & $\begin{array}{l}1.232 \\
(2.24)^{* *}\end{array}$ & $\begin{array}{l}1.200 \\
(1.94)^{*}\end{array}$ & $\begin{array}{l}1.094 \\
(0.61)\end{array}$ & $\begin{array}{l}1.082 \\
(0.59)\end{array}$ \\
\hline Multiown & & & $\begin{array}{l}0.999 \\
(-0.01)\end{array}$ & $\begin{array}{l}0.936 \\
(-.69)\end{array}$ & $\begin{array}{l}0.943 \\
-(0.61)\end{array}$ & $\begin{array}{l}0.939 \\
(-0.65)\end{array}$ & $\begin{array}{l}1.120 \\
(0.79)\end{array}$ \\
\hline Credit Risk & & & $\begin{array}{l}1.091 \\
(1.56)\end{array}$ & $\begin{array}{l}1.080 \\
(1.34)\end{array}$ & $\begin{array}{l}1.093 \\
(1.55)\end{array}$ & $\begin{array}{l}1.092 \\
(1.54)\end{array}$ & $\begin{array}{l}1.280 \\
(2.80)^{* * *}\end{array}$ \\
\hline Intell Property & & & $\begin{array}{l}0.809 \\
(-1.99)^{* *}\end{array}$ & $\begin{array}{l}0.836 \\
(-1.66)^{*}\end{array}$ & $\begin{array}{l}0.833 \\
(-1.69)^{*}\end{array}$ & $\begin{array}{l}0.837 \\
(-1.64)\end{array}$ & $\begin{array}{l}0.957 \\
(-0.26)\end{array}$ \\
\hline Comp Advantage & & & $\begin{array}{l}0.933 \\
(-0.84)\end{array}$ & $\begin{array}{l}0.960 \\
(-0.49)\end{array}$ & $\begin{array}{l}0.952 \\
(-0.58)\end{array}$ & $\begin{array}{l}0.950 \\
(-0.61)\end{array}$ & $\begin{array}{l}0.872 \\
(-1.11)\end{array}$ \\
\hline Product & & & $\begin{array}{l}1.333 \\
(2.20)^{* *}\end{array}$ & $\begin{array}{l}1.306 \\
(1.98)^{* *}\end{array}$ & $\begin{array}{l}1.261 \\
(1.69)^{*}\end{array}$ & $\begin{array}{l}1.255 \\
(1.66)^{*}\end{array}$ & $\begin{array}{l}0.973 \\
(-0.13)\end{array}$ \\
\hline Product \& Service & & & $\begin{array}{l}0.693 \\
(-3.07)^{* * *}\end{array}$ & $\begin{array}{l}0.672 \\
(-3.24)^{* * * *}\end{array}$ & $\begin{array}{l}0.688 \\
(-3.02)^{* * *}\end{array}$ & $\begin{array}{l}0.691 \\
(-2.98)^{* * *}\end{array}$ & $\begin{array}{l}0.718 \\
(-1.65)^{*}\end{array}$ \\
\hline Rural & & & $\begin{array}{l}1.053 \\
(0.51)\end{array}$ & $\begin{array}{l}0.987 \\
(-0.13)\end{array}$ & $\begin{array}{l}0.986 \\
(-0.14)\end{array}$ & $\begin{array}{l}0.987 \\
(-0.12)\end{array}$ & $\begin{array}{l}0.891 \\
(-0.71)\end{array}$ \\
\hline \multicolumn{8}{|l|}{ Owner Characteristics: } \\
\hline Female & & & & $\begin{array}{l}1.172 \\
(1.79)^{*}\end{array}$ & $\begin{array}{l}1.146 \\
(1.53)\end{array}$ & $\begin{array}{l}1.149 \\
(1.56)\end{array}$ & $\begin{array}{l}1.197 \\
(1.40)\end{array}$ \\
\hline Hours Worked & & & & $\begin{array}{l}0.998 \\
(-1.30)\end{array}$ & $\begin{array}{l}0.997 \\
(-1.66)^{*}\end{array}$ & $\begin{array}{l}0.997 \\
(-1.64)\end{array}$ & $\begin{array}{l}0.997 \\
(-1.01)\end{array}$ \\
\hline Prior Experience & & & & $\begin{array}{l}0.984 \\
(-3.53)^{* * *}\end{array}$ & $\begin{array}{l}0.985 \\
(-3.24) * * *\end{array}$ & $\begin{array}{l}0.985 \\
(-3.24) * * *\end{array}$ & $\begin{array}{l}0.988 \\
(-1.73)^{*}\end{array}$ \\
\hline Prior Start-Ups & & & & $\begin{array}{l}1.033 \\
(2.56)^{* *}\end{array}$ & $\begin{array}{l}1.032 \\
(2.56)^{* *}\end{array}$ & $\begin{array}{l}1.031 \\
(2.47)^{* *}\end{array}$ & $\begin{array}{l}1.012 \\
(0.33) \\
\text { (continues) }\end{array}$ \\
\hline
\end{tabular}


Table 3 (continued)

\begin{tabular}{|c|c|c|c|c|c|c|c|}
\hline Variables & 1 & 2 & 3 & 4 & 5 & 6 & 7 \\
\hline \multicolumn{8}{|c|}{ Owner Characteristics: } \\
\hline \multirow{2}{*}{\multicolumn{2}{|c|}{ Owner Age }} & & & 0.956 & 0.959 & 0.961 & 0.952 \\
\hline & & & & $(-2.12)^{* *}$ & $(-1.94)^{*}$ & $(-1.86)^{*}$ & $(-1.63)$ \\
\hline \multirow{2}{*}{\multicolumn{2}{|c|}{ Owner Age ${ }^{2}$}} & & & 1.000 & 1.000 & 1.000 & 1.000 \\
\hline & & & & $(1.96)^{*}$ & $(1.81)^{*}$ & $(1.73)^{*}$ & $(1.47)$ \\
\hline \multirow{2}{*}{\multicolumn{2}{|c|}{ Asian }} & & & 0.537 & 0.525 & 0.532 & 0.634 \\
\hline & & & & $(-2.34)^{* *}$ & $(-2.45)^{* *}$ & $(-2.40)^{* *}$ & $(-1.33)$ \\
\hline \multirow{2}{*}{\multicolumn{2}{|c|}{ Black }} & & & 1.116 & 1.077 & 1.070 & 0.865 \\
\hline & & & & $(0.74)$ & $(0.50)$ & $(0.45)$ & $(-0.77)$ \\
\hline \multirow{2}{*}{\multicolumn{2}{|c|}{ Hispanic }} & & & 1.240 & 1.162 & 1.158 & 1.002 \\
\hline & & & & $(1.36)$ & $(0.92)$ & $(0.90)$ & $(0.01)$ \\
\hline \multirow{2}{*}{\multicolumn{2}{|c|}{ Other }} & & & 1.287 & 1.212 & 1.226 & 1.278 \\
\hline & & & & $(1.01)$ & $(0.77)$ & $(0.81)$ & $(0.65)$ \\
\hline \multirow{2}{*}{\multicolumn{2}{|c|}{ College Education }} & & & 0.720 & 0.723 & 0.727 & 0.688 \\
\hline & & & & $(-2.93)^{* * *}$ & $(-2.86) * * *$ & $(-2.81) * * *$ & $(-2.31)^{* *}$ \\
\hline \multirow{2}{*}{\multicolumn{2}{|c|}{ Graduate Degree }} & & & 0.635 & 0.632 & 0.637 & 0.639 \\
\hline & & & & $(-3.05)^{* * *}$ & $(-3.06)^{* * *}$ & $(-3.01)^{* * *}$ & $(-2.07)^{* *}$ \\
\hline \multicolumn{8}{|c|}{ Other Types of Capital: } \\
\hline \multirow{2}{*}{\multicolumn{2}{|c|}{ Trade Credit }} & & & & 1.066 & 1.068 & 1.005 \\
\hline & & & & & $(0.64)$ & $(0.66)$ & $(0.02)$ \\
\hline \multirow{2}{*}{\multicolumn{2}{|c|}{ Owners' Equity/Totcap }} & & & & 1.022 & 1.026 & 0.765 \\
\hline & & & & & $(0.13)$ & $(0.16)$ & $(-1.13)$ \\
\hline \multirow{2}{*}{\multicolumn{2}{|c|}{ Outsiders' Debt/Totcap }} & & & & 1.038 & 1.047 & 1.053 \\
\hline & & & & & $(0.19)$ & $(0.24)$ & $(0.15)$ \\
\hline \multirow{2}{*}{\multicolumn{2}{|c|}{ Insider Equity }} & & & & 1.273 & 1.270 & 1.317 \\
\hline & & & & & $(1.46)$ & $(1.44)$ & $(1.00)$ \\
\hline \multirow{2}{*}{\multicolumn{2}{|c|}{ Insider Debt }} & & & & 1.196 & 1.199 & 0.970 \\
\hline & & & & & $(1.45)$ & $(1.47)$ & $(-0.14)$ \\
\hline \multirow{2}{*}{\multicolumn{2}{|c|}{ Outsider Equity }} & & & & 0.967 & 0.969 & 1.258 \\
\hline & & & & & $(-0.19)$ & $(-0.18)$ & $(0.72)$ \\
\hline \multirow{2}{*}{\multicolumn{2}{|c|}{ Business Credit*Corp }} & & & & & 0.875 & \\
\hline & & & & & & $(-1.23)$ & \\
\hline \multirow{2}{*}{\multicolumn{2}{|c|}{ Business Credit*Non-Corp }} & & & & & 0.639 & \\
\hline & & & & & & $(-2.91)^{* * *}$ & \\
\hline \multirow{2}{*}{\multicolumn{2}{|c|}{ Personal Credit*Corp }} & & & & & 1.010 & \\
\hline & & & & & & $(0.09)$ & \\
\hline \multirow{2}{*}{\multicolumn{2}{|c|}{ Personal Credit*Non-Corp }} & & & & & 1.046 & \\
\hline & & & & & & $(0.34)$ & \\
\hline $\mathrm{N}$ & 4,293 & 4,301 & 3,010 & 2,904 & 2,869 & 2,869 & 1,253 \\
\hline F-statistic & $5.09 * *$ & $3.24 * *$ & $3.43 * * *$ & $3.16^{* * *}$ & $2.86^{* * *}$ & $2.85 * * *$ & $55.04 * * *$ \\
\hline
\end{tabular}




\section{Table 4}

\section{Credit Use and Firm Performance: Revenue Analysis}

The table reports Weighted Least Squares regressions of revenue on credit, firm, financing and owner characteristics. The dependent variable, Revenue, is the natural logarithm of one plus the level of revenue three years after the firm's start-up (KFS 2007). Independent variables are from KFS 2004 and are described in Table 1. $N$ is the number of observations. $t$-statistics are reported in parentheses. Survey weights applied. ***,**, and * indicate statistical significance at the $1 \%, 5 \%$, and $10 \%$ level, respectively. Industry dummies are included in the regressions 3-6 but are supressed for brevity.

\begin{tabular}{|c|c|c|c|c|c|c|c|}
\hline Variable & 1 & 2 & 3 & 4 & 5 & 6 & 7 \\
\hline Credit & $\begin{array}{l}1.674 \\
(5.86)^{* * *}\end{array}$ & & & & & & \\
\hline Business Credit & & $\begin{array}{l}1.441 \\
(6.49)^{* * *}\end{array}$ & $\begin{array}{l}0.924 \\
(3.69)^{* * *}\end{array}$ & $\begin{array}{l}0.692 \\
(2.77)^{* * *}\end{array}$ & $\begin{array}{l}0.682 \\
(2.49)^{* *}\end{array}$ & & $\begin{array}{l}1.069 \\
(1.99)^{* *}\end{array}$ \\
\hline Personal Credit & & $\begin{array}{l}-0.153 \\
(-0.68)\end{array}$ & $\begin{array}{l}-0.526 \\
(-2.16)^{* *}\end{array}$ & $\begin{array}{l}-0.611 \\
(-2.49)^{* *}\end{array}$ & $\begin{array}{l}-0.549 \\
(-2.11)^{* *}\end{array}$ & & $\begin{array}{l}0.327 \\
(0.67)\end{array}$ \\
\hline Business Credit*Corp & & & & & & $\begin{array}{l}1.030 \\
(3.03) * * *\end{array}$ & \\
\hline Business Credit*Non-Corp & & & & & & $\begin{array}{l}0.186 \\
(0.46)\end{array}$ & \\
\hline Personal Credit*Corp & & & & & & $\begin{array}{l}-0.539 \\
(-1.67)^{*}\end{array}$ & \\
\hline Personal Credit*Non-Corp & & & & & & $\begin{array}{l}-0.571 \\
(-1.43)\end{array}$ & \\
\hline Firm Characteristics: & & & & & & & \\
\hline$\overline{\text { Ln (Revenue } 2004+1)}$ & & & $\begin{array}{l}0.270 \\
(10.37)^{* * *}\end{array}$ & $\begin{array}{l}0.214 \\
(7.91)^{* * *}\end{array}$ & $\begin{array}{l}0.209 \\
(7.60)^{* * *}\end{array}$ & $\begin{array}{l}0.209 \\
(7.62) * * *\end{array}$ & $\begin{array}{l}0.200 \\
(4.32)^{* * *}\end{array}$ \\
\hline Corp & & & $\begin{array}{l}1.650 \\
(5.79)^{* * *}\end{array}$ & $\begin{array}{l}1.445 \\
(4.90)^{* * *}\end{array}$ & $\begin{array}{l}1.392 \\
(4.70)^{* * *}\end{array}$ & $\begin{array}{l}0.980 \\
(2.12)^{* *}\end{array}$ & $\begin{array}{l}1.429 \\
(2.87)^{* * *}\end{array}$ \\
\hline Multiown & & & $\begin{array}{l}0.204 \\
(0.72)\end{array}$ & $\begin{array}{l}0.222 \\
(0.77)\end{array}$ & $\begin{array}{l}0.109 \\
(0.38)\end{array}$ & $\begin{array}{l}0.098 \\
(0.34)\end{array}$ & $\begin{array}{l}0.108 \\
(0.20)\end{array}$ \\
\hline Credit Risk & & & $\begin{array}{l}-0.250 \\
(-1.38)\end{array}$ & $\begin{array}{l}-0.200 \\
(-1.12)\end{array}$ & $\begin{array}{l}-0.149 \\
(-0.83)\end{array}$ & $\begin{array}{l}-0.148 \\
(-0.82)\end{array}$ & $\begin{array}{l}-0.091 \\
(-0.31)\end{array}$ \\
\hline Intell Property & & & $\begin{array}{l}-0.088 \\
(0.30)\end{array}$ & $\begin{array}{l}-0.130 \\
(0.44)\end{array}$ & $\begin{array}{l}-0.161 \\
(-0.54)\end{array}$ & $\begin{array}{l}-0.148 \\
(-0.50)\end{array}$ & $\begin{array}{l}0.074 \\
(0.15)\end{array}$ \\
\hline Comp Advantage & & & $\begin{array}{l}0.637 \\
(2.34)^{* *}\end{array}$ & $\begin{array}{l}0.442 \\
(1.62)\end{array}$ & $\begin{array}{l}0.484 \\
(1.76)^{*}\end{array}$ & $\begin{array}{l}0.471 \\
(1.72)^{*}\end{array}$ & $\begin{array}{l}0.692 \\
(1.64)\end{array}$ \\
\hline Product & & & $\begin{array}{l}-0.009 \\
(-0.02)\end{array}$ & $\begin{array}{l}-0.064 \\
(-0.13)\end{array}$ & $\begin{array}{l}-0.139 \\
(-0.29)\end{array}$ & $\begin{array}{l}-0.144 \\
(-0.30)\end{array}$ & $\begin{array}{l}-0.584 \\
(-0.78)\end{array}$ \\
\hline Product \& Service & & & $\begin{array}{l}0.968 \\
(2.30)^{* *}\end{array}$ & $\begin{array}{l}0.751 \\
(1.77)^{*}\end{array}$ & $\begin{array}{l}0.724 \\
(1.71)^{*}\end{array}$ & $\begin{array}{l}0.729 \\
(1.73)^{*}\end{array}$ & $\begin{array}{l}0.945 \\
(1.37)\end{array}$ \\
\hline Rural & & & $\begin{array}{l}-0.259 \\
(-0.83)\end{array}$ & $\begin{array}{l}-0.212 \\
(-0.66)\end{array}$ & $\begin{array}{l}-0.263 \\
(-0.81)\end{array}$ & $\begin{array}{l}-0.266 \\
(-0.82)\end{array}$ & $\begin{array}{l}0.687 \\
(1.34)\end{array}$ \\
\hline
\end{tabular}


Table 4 (continued)

\begin{tabular}{|c|c|c|c|c|c|c|c|}
\hline Variable & 1 & 2 & 3 & 4 & 5 & 6 & 7 \\
\hline \multicolumn{8}{|l|}{ Owner Characteristics: } \\
\hline Female & & & & $\begin{array}{l}-0.844 \\
(-2.81)^{* * *}\end{array}$ & $\begin{array}{l}-0.769 \\
(-2.60)^{* * *}\end{array}$ & $\begin{array}{l}-0.749 \\
(-2.55) * *\end{array}$ & $\begin{array}{l}-0.768 \\
(-1.68)^{*}\end{array}$ \\
\hline Hours Worked & & & & $\begin{array}{l}0.027 \\
(4.70) * * *\end{array}$ & $\begin{array}{l}0.027 \\
(4.47)^{* * *}\end{array}$ & $\begin{array}{l}0.027 \\
(4.46)^{* * *}\end{array}$ & $\begin{array}{l}0.036 \\
(3.82) * * *\end{array}$ \\
\hline Prior Experience & & & & $\begin{array}{l}0.010 \\
(0.76)\end{array}$ & $\begin{array}{l}0.008 \\
(0.64)\end{array}$ & $\begin{array}{l}0.008 \\
(0.61)\end{array}$ & $\begin{array}{l}0.011 \\
(0.53)\end{array}$ \\
\hline Prior Start-Ups & & & & $\begin{array}{l}0.055 \\
(0.92)\end{array}$ & $\begin{array}{l}0.027 \\
(0.45)\end{array}$ & $\begin{array}{l}0.028 \\
(0.46)\end{array}$ & $\begin{array}{l}0.114 \\
(1.28)\end{array}$ \\
\hline Owner Age & & & & $\begin{array}{l}0.001 \\
(0.02)\end{array}$ & $\begin{array}{l}-0.022 \\
(-0.29)\end{array}$ & $\begin{array}{l}-0.022 \\
(-0.28)\end{array}$ & $\begin{array}{l}0.103 \\
(0.95)\end{array}$ \\
\hline Owner Age $^{2}$ & & & & $\begin{array}{l}0.000 \\
(0.50)\end{array}$ & $\begin{array}{l}0.000 \\
(0.14)\end{array}$ & $\begin{array}{l}0.000 \\
(0.14)\end{array}$ & $\begin{array}{l}-0.001 \\
(-1.30)\end{array}$ \\
\hline Asian & & & & $\begin{array}{l}-1.184 \\
(-1.58)\end{array}$ & $\begin{array}{l}-1.101 \\
(-1.49)\end{array}$ & $\begin{array}{l}-1.068 \\
(-1.45)\end{array}$ & $\begin{array}{l}-0.908 \\
(-0.82)\end{array}$ \\
\hline Black & & & & $\begin{array}{l}-1.630 \\
(-3.28) * * *\end{array}$ & $\begin{array}{l}-1.556 \\
(-3.11)^{* * *}\end{array}$ & $\begin{array}{l}-1.602 \\
(-3.21)^{* * *}\end{array}$ & $\begin{array}{l}-1.427 \\
(-2.25)^{* *}\end{array}$ \\
\hline Hispanic & & & & $\begin{array}{l}-1.247 \\
(-2.03)^{* *}\end{array}$ & $\begin{array}{l}-1.160 \\
(-1.88)^{*}\end{array}$ & $\begin{array}{l}-1.180 \\
(-1.92)^{*}\end{array}$ & $\begin{array}{l}-0.553 \\
(-0.66)\end{array}$ \\
\hline Other & & & & $\begin{array}{l}-1.447 \\
(-1.47)\end{array}$ & $\begin{array}{l}-1.383 \\
(-1.39)\end{array}$ & $\begin{array}{l}-1.380 \\
(-1.40)\end{array}$ & $\begin{array}{l}-0.150 \\
(-0.13)\end{array}$ \\
\hline College Education & & & & $\begin{array}{l}0.031 \\
(0.08)\end{array}$ & $\begin{array}{l}-0.147 \\
(-0.37)\end{array}$ & $\begin{array}{l}-0.137 \\
(-0.35)\end{array}$ & $\begin{array}{l}-1.139 \\
(-1.91)^{*}\end{array}$ \\
\hline Graduate Degree & & & & $\begin{array}{l}0.362 \\
(0.76)\end{array}$ & $\begin{array}{l}0.128 \\
(0.27)\end{array}$ & $\begin{array}{l}0.162 \\
(0.34)\end{array}$ & $\begin{array}{l}-0.950 \\
(-1.28)\end{array}$ \\
\hline Other Types of Capital & & & & & & & \\
\hline Trade Credit & & & & & $\begin{array}{l}0.786 \\
(2.60)^{* * *}\end{array}$ & $\begin{array}{l}0.787 \\
(2.61)^{* * *}\end{array}$ & $\begin{array}{l}1.217 \\
(1.47)\end{array}$ \\
\hline Owners' Equity/Totcap & & & & & $\begin{array}{l}0.404 \\
(0.78)\end{array}$ & $\begin{array}{l}0.381 \\
(0.73)\end{array}$ & $\begin{array}{l}2.373 \\
(2.52)^{* *}\end{array}$ \\
\hline Outsiders' Debt/Totcap & & & & & $\begin{array}{l}0.497 \\
(0.81)\end{array}$ & $\begin{array}{l}0.495 \\
(0.80)\end{array}$ & $\begin{array}{l}0.442 \\
(0.34)\end{array}$ \\
\hline Insider Equity & & & & & $\begin{array}{l}-1.189 \\
(-1.94)^{*}\end{array}$ & $\begin{array}{l}-1.193 \\
(-1.95)^{*}\end{array}$ & $\begin{array}{l}-1.696 \\
(-1.34)\end{array}$ \\
\hline Insider Debt & & & & & $\begin{array}{l}0.191 \\
(0.46)\end{array}$ & $\begin{array}{l}0.189 \\
(0.45)\end{array}$ & $\begin{array}{l}1.471 \\
(1.86)^{*}\end{array}$ \\
\hline Outsider Equity & & & & & $\begin{array}{l}1.376 \\
(2.59)^{* * *}\end{array}$ & $\begin{array}{l}1.359 \\
(2.56)^{* *}\end{array}$ & $\begin{array}{l}2.076 \\
(1.82)^{*}\end{array}$ \\
\hline Constant & $\begin{array}{l}7.540 \\
(29.27)^{* * *}\end{array}$ & $\begin{array}{l}8.270 \\
(41.60) * * *\end{array}$ & $\begin{array}{l}4.693 \\
(2.85)^{* * *}\end{array}$ & $\begin{array}{l}4.989 \\
(2.11)^{* *}\end{array}$ & $\begin{array}{l}4.938 \\
(2.06)^{* *}\end{array}$ & $\begin{array}{l}5.162 \\
(2.13)^{* *}\end{array}$ & $\begin{array}{l}-2.842 \\
(0.66)\end{array}$ \\
\hline $\mathrm{N}$ & 2,899 & 2,903 & 2,054 & 1,980 & 1,953 & 1,953 & 795 \\
\hline $\mathrm{R}^{2}$ & $2 \%$ & $2 \%$ & $17 \%$ & $20 \%$ & $21 \%$ & $21 \%$ & $20 \%$ \\
\hline
\end{tabular}




\section{Table 5}

\section{Use of Different Types of Credit at a Firm's Start-Up}

The table reports the percentage of firms that use credit and certain types of credit at the firm's start-up and compares the use of credit between Corps and Non-Corps. Corps indicates firms that are organized as S-corporations, C-corporations, or Limited Liability Companies (Partnerships). Non-Corps indicates firms that are organized as sole proprietorships or partnerships. Data are from 2004 Kauffman Firm Survey. Panel A presents the distribution for all firms. Panels B and C examine firms that use some type of credit. Last column reports $z$-statistic for the difference in proportions between Corps and Non-Corps. $* * *, * *$, and * indicate that the difference is statistically significant at the $1 \%, 5 \%$, and $10 \%$ level, respectively. Survey weights applied. N/A denotes cases with less than ten observations that cannot be reported according to the disclose rules.

Panel A: Percentage of firms that use a certain type of credit

\begin{tabular}{|c|c|c|c|c|}
\hline Credit Category & Full Sample & Corps & Non-Corps & $z$-statistic \\
\hline Credit (any type) & $76.1 \%$ & $79.6 \%$ & $71.0 \%$ & $6.31 * * *$ \\
\hline Trade Credit & $23.8 \%$ & $26.7 \%$ & $19.7 \%$ & $6.10 * * *$ \\
\hline Business Credit & $44.4 \%$ & $51.2 \%$ & $34.8 \%$ & $10.91 * * *$ \\
\hline Business Credit Card Owner Name & $28.7 \%$ & $33.1 \%$ & $22.5 \%$ & $7.42 * * *$ \\
\hline Business Credit Card & $24.3 \%$ & $27.8 \%$ & $19.3 \%$ & $6.94 * * *$ \\
\hline Business Credit Line & $8.6 \%$ & $11.0 \%$ & $5.3 \%$ & $7.27 * * *$ \\
\hline Business Bank Loan & $6.8 \%$ & $9.0 \%$ & $3.7 \%$ & $7.46 * * *$ \\
\hline Business Loan from Nonbank Institution & $1.7 \%$ & $2.1 \%$ & $1.3 \%$ & $2.94 * * *$ \\
\hline Business Loan from Government & $0.9 \%$ & $1.0 \%$ & $0.7 \%$ & 1.39 \\
\hline Business Loan from Other Businesses & $0.3 \%$ & $0.4 \%$ & N/A & 1.34 \\
\hline Business Loan from Other Sources & $0.5 \%$ & $0.6 \%$ & $0.4 \%$ & 0.34 \\
\hline Personal Credit & $54.9 \%$ & $55.8 \%$ & $53.7 \%$ & 0.70 \\
\hline Personal Bank Loan by Primary Owner & $17.3 \%$ & $19.4 \%$ & $14.4 \%$ & $4.30 * * *$ \\
\hline Personal Bank Loan by Other Owners & $2.6 \%$ & $4.1 \%$ & $0.5 \%$ & $1.8^{*}$ \\
\hline Primary Owner's Credit Card & $46.2 \%$ & $45.1 \%$ & $47.6 \%$ & $2.00 * *$ \\
\hline Other Owner's Credit Card & $5.7 \%$ & $8.1 \%$ & $2.3 \%$ & $2.72 * * *$ \\
\hline Number of Observations & 4,928 & 3,038 & 1,890 & \\
\hline
\end{tabular}


Table 5 (continued)

Use of Different Types of Credit at a Firm's Start-Up

Panel B: Percentage of firms that use only one type of credit

\begin{tabular}{|c|c|c|c|c|}
\hline Credit Category & Full Sample & Corps & Non-Corps & $z$-statistic \\
\hline Trade Credit Only & $5.5 \%$ & $5.1 \%$ & $6.0 \%$ & 0.68 \\
\hline Business Credit Only & $16.3 \%$ & $17.4 \%$ & $14.4 \%$ & $3.22 * * *$ \\
\hline Personal Credit Only & $28.7 \%$ & $23.7 \%$ & $36.7 \%$ & $8.83^{* * *}$ \\
\hline Number of Observations & 3,752 & 2,408 & 1,344 & \\
\hline \multicolumn{5}{|c|}{ Panel C: Percentage of firms that use a combination of credit type } \\
\hline Credit Category & Full Sample & Corps & Non-Corps & $z$-statistic \\
\hline Trade Credit and Business Credit & $18.4 \%$ & 21.5 & $13.5 \%$ & $-6.46 * * *$ \\
\hline Trade Credit and Personal Credit & $19.8 \%$ & $21.1 \%$ & $17.7 \%$ & $-3.25 * * *$ \\
\hline Business Credit and Personal Credit & $36.1 \%$ & $39.5 \%$ & $30.7 \%$ & $-4.74 * * *$ \\
\hline Trade, Business, and Personal Credit & $12.4 \%$ & $14.2 \%$ & $9.5 \%$ & $-4.79 * * *$ \\
\hline Number of Observations & 3,752 & 2,408 & 1,344 & \\
\hline
\end{tabular}




\section{Table 6}

Differences between Firms that Use Credit and Firms that Do Not Use Credit: Univariate Analysis

The table reports differences in firm and owner characteristics between firms that use credit and firms that use no credit. Panel A includes the full sample of firms. Panels B and C exclude firms that use no credit. Panel B presents differences in means between firms that do, and don not, use business credit. Panel C presents differences in means between firms that do, and do not, use personal credit. In each panel, columns 1 and 2 report mean values of a given variable for firms that use (column 1), or do not use (column 2), credit. Column 3 reports $p$-values for difference-in-means $t$-tests. Column 4 reports the number of nonmissing observations $\mathrm{N}$ for that variable. Variable definitions are provided in Table 1 . Survey weights have been applied. ***, **, and $*$ indicate that the difference in means is statistically significant at the $1 \%, 5 \%$, and $10 \%$ level, respectively.

\begin{tabular}{|c|c|c|c|c|c|c|c|c|c|c|c|c|c|c|c|}
\hline \multirow[t]{2}{*}{ Variable } & \multicolumn{5}{|c|}{ Panel A: Use Any Credit? } & \multicolumn{5}{|c|}{ Panel B: Use Business Credit? } & \multicolumn{5}{|c|}{ Panel C: Use Personal Credit? } \\
\hline & 1 & 2 & 3 & & 4 & 1 & 2 & 3 & & 4 & 1 & 2 & 3 & & 4 \\
\hline Firm Characteristics: & Yes & $\mathrm{No}$ & p-value & & $\mathrm{N}$ & Yes & No & p-value & & $\mathrm{N}$ & Yes & No & p-value & & $\mathrm{N}$ \\
\hline $\ln ($ Revenue +1$)$ & 7.27 & 4.13 & 0.000 & $* * *$ & 4,740 & 7.69 & 6.7 & 0.000 & $* * *$ & 3,618 & 7.05 & 7.86 & 0.000 & $* * *$ & 3,612 \\
\hline $\ln ($ Total Assets +1$)$ & 9.68 & 7.24 & 0.000 & $* * *$ & 4,816 & 10.19 & 8.96 & 0.000 & $* * *$ & 3,678 & 9.52 & 10.08 & 0.000 & $* * *$ & 3,671 \\
\hline Corp & 0.29 & 0.23 & 0.000 & $* * *$ & 4,918 & 0.34 & 0.23 & 0.000 & $* * *$ & 3,751 & 0.28 & 0.33 & 0.006 & $* * *$ & 3,744 \\
\hline Credit Risk & 3.4 & 3.56 & 0.000 & $* * *$ & 3,597 & 3.33 & 3.49 & 0.000 & $* * *$ & 2,775 & 3.43 & 3.3 & 0.000 & $* * *$ & 2,770 \\
\hline Rural & 0.16 & 0.15 & 0.371 & & 4,918 & 0.16 & 0.16 & 0.866 & & 3,751 & 0.16 & 0.16 & 0.948 & & 3,744 \\
\hline Multiown & 0.36 & 0.3 & 0.001 & $* * *$ & 4,915 & 0.4 & 0.31 & 0 & $* * *$ & 3,750 & 0.34 & 0.41 & 0.001 & $* * *$ & 3,743 \\
\hline \multicolumn{16}{|l|}{ Owner Characteristics: } \\
\hline Owner Age & 44.53 & 44.43 & 0.817 & & 4,855 & 44.64 & 44.35 & 0.475 & & 3,709 & 44.38 & 44.88 & 0.263 & & 3,702 \\
\hline Prior Experience & 11.69 & 12.36 & 0.098 & $*$ & 4,902 & 11.88 & 11.39 & 0.213 & & 3,742 & 11.08 & 13.24 & 0.00 & $* * *$ & 3,735 \\
\hline Prior Start-ups & 0.98 & 0.92 & 0.581 & & 4,888 & 1 & 0.94 & 0.517 & & 3,733 & 0.92 & 1.13 & 0.128 & & 3,726 \\
\hline Female & 0.3 & 0.33 & 0.100 & & 4,912 & 0.28 & 0.33 & 0.004 & $* * *$ & 3,748 & 0.32 & 0.25 & 0.00 & $* * *$ & 3,741 \\
\hline Asian & 0.05 & 0.04 & 0.387 & & 4,880 & 0.05 & 0.04 & 0.096 & $*$ & 3,724 & 0.05 & 0.04 & 0.423 & & 3,717 \\
\hline Black & 0.07 & 0.18 & 0.000 & $* * *$ & 4,880 & 0.05 & 0.08 & 0.003 & $* * *$ & 3,724 & 0.07 & 0.07 & 0.989 & & 3,717 \\
\hline White & 0.8 & 0.69 & 0.000 & $* * *$ & 4,880 & 0.81 & 0.78 & 0.113 & & 3,724 & 0.79 & 0.81 & 0.228 & & 3,717 \\
\hline Other Race & 0.02 & 0.03 & 0.915 & & 4,880 & 0.03 & 0.02 & 0.696 & & 3,724 & 0.03 & 0.02 & 0.537 & & 3,717 \\
\hline High School & 0.14 & 0.17 & 0.016 & $* *$ & 4,889 & 0.13 & 0.14 & 0.382 & & 3,734 & 0.13 & 0.14 & 0.491 & & 3,727 \\
\hline Some College & 0.37 & 0.4 & 0.111 & & 4,889 & 0.34 & 0.41 & 0 & $* * *$ & 3,734 & 0.38 & 0.32 & 0.004 & $* * *$ & 3,727 \\
\hline College Degree & 0.3 & 0.29 & 0.307 & & 4,889 & 0.32 & 0.27 & 0.005 & $* * *$ & 3,734 & 0.29 & 0.33 & 0.033 & $* *$ & 3,727 \\
\hline College Education & 0.67 & 0.68 & 0.492 & & 4,889 & 0.66 & 0.68 & 0.239 & & 3,734 & 0.67 & 0.66 & 0.435 & & 3,727 \\
\hline Graduate Degree & 0.19 & 0.15 & 0.000 & $* * *$ & 4,889 & 0.21 & 0.17 & 0.024 & $* *$ & 3,734 & 0.19 & 0.2 & 0.75 & & 3,727 \\
\hline
\end{tabular}


Table 7

Factors Explaining Use of Credit at a Firm's Start-Up

The table reports odds ratios from a weighted biprobit regression model with sample selection. The sample includes Kauffman Firm Survey 2004 start-up firms. Column 2 presents the results from the first stage probit model, examining the determinants of credit use. The dependent variable, Credit, equals 1 if the firm reports that it uses trade, business, or personal credit, and equals 0 otherwise. Column 3 presents the results from the second stage regression. The dependent variable, Business Credit, equals 1 if the firm reports it uses business credit, and equals 0 otherwise. Column 4 presents the results from the second stage regression. The dependent variable, Personal Credit, equals 1 if the firm reports it uses personal credit, and equals 0 otherwise. $t$-statistics are in parentheses. Variable definitions appear in Table 1. Industry dummies (based on two-digit NAICS code) are included but omitted from the table for the sake of brevity. $N$ is the number of observations. Survey weights applied. ***, **, and * indicate statistical significance at the $1 \%, 5 \%$, and $10 \%$ level, respectively.

\begin{tabular}{|c|c|c|c|}
\hline & $\begin{array}{l}\text { 1st stage: } \\
\text { Credit }\end{array}$ & $\begin{array}{l}\text { 2nd Stage: } \\
\text { Business Credit }\end{array}$ & $\begin{array}{l}\text { 2nd Stage: } \\
\text { Personal Credit }\end{array}$ \\
\hline \multicolumn{4}{|l|}{ Firm Characteristics: } \\
\hline$\overline{\text { Ln (Revenue } 2004+1)}$ & $\begin{array}{l}1.043 \\
(6.73) * * *\end{array}$ & $\begin{array}{l}1.030 \\
(5.33)^{* * *}\end{array}$ & $\begin{array}{l}0.977 \\
(-1.81)^{*}\end{array}$ \\
\hline Ln (Total Assets+1) & $\begin{array}{l}1.058 \\
(5.97)^{* * *}\end{array}$ & $\begin{array}{l}1.077 \\
(7.50)^{* * *}\end{array}$ & $\begin{array}{l}0.969 \\
(-1.51)\end{array}$ \\
\hline Corp & $\begin{array}{l}1.155 \\
(2.11)^{* *}\end{array}$ & $\begin{array}{l}1.344 \\
(4.72)^{* * *}\end{array}$ & $\begin{array}{l}0.973 \\
(-0.33)\end{array}$ \\
\hline Multiown & $\begin{array}{l}0.953 \\
(-0.69)\end{array}$ & $\begin{array}{l}1.101 \\
(1.54)\end{array}$ & $\begin{array}{l}0.828 \\
(-2.41)^{* *}\end{array}$ \\
\hline Credit Risk & $\begin{array}{l}0.886 \\
(-2.71)^{* * *}\end{array}$ & $\begin{array}{l}0.890 \\
(-2.98) * * *\end{array}$ & $\begin{array}{l}1.104 \\
(2.08)^{* *}\end{array}$ \\
\hline Intell Property & $\begin{array}{l}0.904 \\
(-1.27)\end{array}$ & $\begin{array}{l}1.102 \\
(1.37)\end{array}$ & $\begin{array}{l}1.051 \\
(0.58)\end{array}$ \\
\hline Comp Advantage & $\begin{array}{l}1.151 \\
(2.20)^{* *}\end{array}$ & $\begin{array}{l}0.992 \\
(-0.14)\end{array}$ & $\begin{array}{l}0.927 \\
(-0.97)\end{array}$ \\
\hline Product & $\begin{array}{l}1.385 \\
(2.86)^{* * *}\end{array}$ & $\begin{array}{l}1.000 \\
(0.00)\end{array}$ & $\begin{array}{l}0.976 \\
(-0.17)\end{array}$ \\
\hline Product \& Service & $\begin{array}{l}0.809 \\
(-1.95)^{*}\end{array}$ & $\begin{array}{l}1.012 \\
(0.14)\end{array}$ & $\begin{array}{l}0.971 \\
(-0.24)\end{array}$ \\
\hline Rural & $\begin{array}{l}0.952 \\
(-0.61)\end{array}$ & $\begin{array}{l}0.979 \\
(-0.29) \\
\end{array}$ & $\begin{array}{l}0.993 \\
(-0.08) \\
\end{array}$ \\
\hline
\end{tabular}


Table 7 (continued)

\begin{tabular}{|c|c|c|c|}
\hline & $\begin{array}{l}\text { 1st stage: } \\
\text { Credit }\end{array}$ & $\begin{array}{l}\text { 2nd Stage: } \\
\text { Business Credit }\end{array}$ & $\begin{array}{l}\text { 2nd Stage: } \\
\text { Personal Credit }\end{array}$ \\
\hline \multicolumn{4}{|l|}{ Owner Characteristics: } \\
\hline Female & $\begin{array}{l}0.941 \\
(-0.85)\end{array}$ & $\begin{array}{l}0.917 \\
(-1.38)\end{array}$ & $\begin{array}{l}1.175 \\
(2.12)^{* *}\end{array}$ \\
\hline Hours Worked & $\begin{array}{l}1.004 \\
(2.40)^{* *}\end{array}$ & $\begin{array}{l}1.003 \\
(2.27)^{* *}\end{array}$ & $\begin{array}{l}1.001 \\
(0.60)\end{array}$ \\
\hline Prior Experience & $\begin{array}{l}0.991 \\
(-2.88) * * *\end{array}$ & $\begin{array}{l}0.996 \\
(-1.37)\end{array}$ & $\begin{array}{l}0.991 \\
(-1.82)^{*}\end{array}$ \\
\hline Prior Start-Ups & $\begin{array}{l}0.996 \\
(-0.25)\end{array}$ & $\begin{array}{l}0.986 \\
(-1.25)\end{array}$ & $\begin{array}{l}0.984 \\
(-1.43)\end{array}$ \\
\hline Owner Age & $\begin{array}{l}1.006 \\
(0.34)\end{array}$ & $\begin{array}{l}1.018 \\
(1.14)\end{array}$ & $\begin{array}{l}0.987 \\
(-0.67)\end{array}$ \\
\hline Owner Age $^{2}$ & $\begin{array}{l}1.000 \\
(0.36)\end{array}$ & $\begin{array}{l}1.000 \\
(1.24)\end{array}$ & $\begin{array}{l}1.000 \\
(0.93)\end{array}$ \\
\hline Asian & $\begin{array}{l}1.003 \\
(0.02)\end{array}$ & $\begin{array}{l}1.123 \\
(0.79)\end{array}$ & $\begin{array}{l}1.038 \\
(0.22)\end{array}$ \\
\hline Black & $\begin{array}{l}0.568 \\
(-5.33) * * *\end{array}$ & $\begin{array}{l}0.685 \\
(-3.46)^{* * *}\end{array}$ & $\begin{array}{l}0.832 \\
(-0.62)\end{array}$ \\
\hline Hispanic & $\begin{array}{l}0.972 \\
(-0.21)\end{array}$ & $\begin{array}{l}0.885 \\
(-1.09)\end{array}$ & $\begin{array}{l}0.97 \\
(-0.23)\end{array}$ \\
\hline Other & $\begin{array}{l}1.068 \\
(0.32)\end{array}$ & $\begin{array}{l}1.279 \\
(1.37)\end{array}$ & $\begin{array}{l}1.235 \\
(0.99)\end{array}$ \\
\hline College Education & $\begin{array}{l}1.196 \\
(1.96)^{* *}\end{array}$ & $\begin{array}{l}1.081 \\
(0.94)\end{array}$ & $\begin{array}{l}1.096 \\
(0.82)\end{array}$ \\
\hline Graduate Degree & $\begin{array}{l}1.582 \\
(4.01)^{* * *}\end{array}$ & $\begin{array}{l}1.202 \\
(1.82)^{*}\end{array}$ & $\begin{array}{l}1.018 \\
(0.11)\end{array}$ \\
\hline Other Types of Capital: & & & \\
\hline$\overline{\log (\text { Owners' Equity }+1)}$ & $\begin{array}{l}1.014 \\
(1.76)^{*}\end{array}$ & $\begin{array}{l}1.006 \\
(0.81)\end{array}$ & $\begin{array}{l}1.01 \\
(1.05)\end{array}$ \\
\hline Insider Equity & $\begin{array}{l}1.609 \\
(2.85)^{* * *}\end{array}$ & $\begin{array}{l}1.214 \\
(1.64)\end{array}$ & $\begin{array}{l}0.956 \\
(-0.30)\end{array}$ \\
\hline Insider Debt & $\begin{array}{l}0.980 \\
(-0.22)\end{array}$ & $\begin{array}{l}0.837 \\
(-2.19)^{* *}\end{array}$ & $\begin{array}{l}1.260 \\
(2.35)^{* *}\end{array}$ \\
\hline Outsider Equity & $\begin{array}{l}0.909 \\
(-0.64)\end{array}$ & $\begin{array}{l}0.925 \\
(-0.63)\end{array}$ & $\begin{array}{l}1.049 \\
(0.36)\end{array}$ \\
\hline $\mathrm{N}$ & 3,243 & 3,243 & 3,243 \\
\hline
\end{tabular}

